\title{
『법화현의』의 관심론(觀心論)
}

지창규

\section{[국문 초록]}

『法華經』의 현의를 해석하고 있는 『法華玄義』는 당초 교문 저작이라 하여 智顗의 修證과는 다소 거리가 있는 것으로 생각되고, 『법화경』의 현의를 밝히는 데 주력하는 저작으로 이해되어왔다. 더구나 五時八敎와 같은 천태 의 대표적인 교판조직이 소개되어 있으므로 일반에는 교판서로 알려져 있다. 그런데『妙法蓮華經』의 玄義를 밝히면서 천태교상문의 근간을 이루 는 『법화현의』에는 의외의 觀心論이 보인다.

『법화현의』는 오중현의를 七番共解와 五重各釋으로 풀이하는 가운데 칠번 공해에서는 관심단을 설정하여 표番에 대한 철저한 관심을 요구하고 있고, 오중각석에서는 名體宗用敎마다 관심단을 제정하여 교상을 관심하도록 하고 있다. 칠번공해에서 관심단을 설정하여 標章·引證·生起·開合·料簡을 관심토록 한 것은 연구방법론인 칠번공해마저 관찰함으로써 呚觀相資를 취하도록 한 것이다. 이런 토대 위에 오중현의마다 관심단을 제정하여, 名玄義에서는 妙法을 圓五行과 十乘觀法 吕 經觀으로, 體玄義에서는 諸法 實相을 십승관법으로, 敎相玄義에서는 醍醐의 妙味를 三種敎觀으로 觀心 케 하는 것이다.

그렇다고 하면 교문 저작인 『법화현의』에 왜 이토록 呚相 이상으로 觀心이 강조된 것인가. 이것은 『법화경』의 현의를 밝히는 교상의 단순한 이해보다 는 『법화경』의 실상묘법을 수증하는 것에 궁극적 의의가 있음을 절감한 智顗가 교관겸수의 특색을 유감없이 발휘한 것이라 볼 수 있다. 평생 수증으 로 일관한 智顗로서는 觀心이 實相妙法의 총결이라 해도 과언이 아닌 이상, 
제법의 근본원리인 제법실상은 관문을 통해서만 들어갈 수 있으나 그럼에

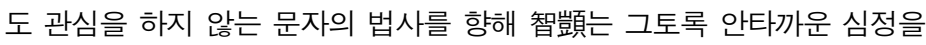
토로하며 탄식하였던 것이고, 또 실상문자를 이해한 바탕위에 실상묘법에 대한 이해가 관심을 이끈다는 점에서 교상적 이해를 무시하는 암증의 선사 를 향해 智顗는 뼈저린 심정으로 무척이나 애석해하고 질타했던 것이다. 『법화경』의 교상과 관법을 통해 證悟를 이룬 智顗는 敉나 觀에 치우치는 문자의 법사와 암증의 선사를 동시에 비판하면서 행인들에게 교관겸수의 가르침을 제시한 것은 분명하다. 더구나 관심을 가지고 실상묘법으로 통하 는 길을 밝힌 智顗로서는 『법화현의』가 법화의 현의를 밝히는 교문저작이 라는 점에서 관심에 대한 강조에 더욱 유별난 모습을 보였다고 하겠다. 이와 같이 오중현의 전체를 통하여 開顯 뒤에 바로 觀心을 둔 것은 聞慧를 구족케 하는 것이 그 목적이라 할 수 있다. 이로 인해『법화현의』에서 觀心이 開顯 이상으로 중요한 축이므로『법화현의』전체를 통하여 觀心을 체득해가는 방법이 교상저작임에 불구하고 관심저작 이상으로 조직적으로 설명되어 있는 것이다. 이러한 『법화현의』의 교관체계는 『법화경』의 현의 를 圓融敉相과 圓頓止觀으로 해석하면서 聞慧萧修와 㸚觀相資를 역설할 뿐만 아니라 대소승을 막론한 불교 경전을 四敉의 교상과 관심으로 조직함 으로써 복잡다단한 불교 교리와 수행을 체계화한 것이다. 결론적으로 말하 면 『법화현의』는 經敉와 禪觀가 절묘하게 만나는 독보적이고 탁월한 교관 저작이라 해도 좋을 것이다.

주제어: 법화현의(法華玄義), 원융교상(圓融敉相), 원돈지관(圓頓止觀), 칠 번공해(七番共解), 오중각석(五重各釋)

\section{1.『法華玄義』의 觀門}

『法華文句』・法華玄義』・摩訶止觀』으로 이루어져 있는 法華三大 部는 天台三大部라 하여 圓融敉相과 圓頓止觀을 담고 있다. 그 중『법 화경』의 현의를 해석하고 있는 『法華玄義』는 당초 교문저작이라 하여 智顗의 修登과는 다소 거리가 있는 것으로 생각되고, 『法華經』의 현의 를 밝히는 데 주력하는 저작으로 이해되어왔다. 더구나 五時八敉와 같 은 천태의 대표적인 교판조직이 소개되어 있으므로 일반에는 천태교 
판서로 알려져 있다. 그런데『妙法蓮華經』의 玄義를 밝히면서 천태교 상문의 근간을 이루는 『法華玄義』에는 의외의 觀心論이 보인다. 觀心 이란 法相을 자기 마음에 거두어 자신의 마음에 본래 갖추어진 이치를 비추어 보는 것이다. 妙理를 자기 마음에 이끎으로써 妙觀이 생기도록 하는 것이다. 즉 교리를 관행하는 것으로서 교리와 관행을 하나로 하 는 천태의 특유한 수행방법이다.

이런 觀心이『법화경』의 五重玄義를 七番共解와 五重各說로 풀이하 는 가운데 전편에 통해 펼쳐져 있다. 먼저 七番共解에서는 관심의 구 체적인 방법이 여섯째 觀心段에 담겨져 있다. 여기서는 標章으로부터 料簡에 이르는 五章을 관심으로 풀이하고 있다. 또한 五重玄義를 각론 하는 본론에서는 각 ⿱⿱亠䒑⿱日十)은 물론 각 節도 觀心으로 결론을 맺고 있다. 더 구나『법화현의』의 본령이라 할 수 있는 迹門十妙에서는 章節이 거의 모두 觀心으로 결론을 맺고 있는 것은 교문저작이 필요 이상으로 관심 으로 치우친 것 같아 다소 의아하게 생각되기도 한다. 그 가운데에서 도 적문십묘 중 行妙와 位妙에서는 본격적인 행법이 소개되어 있다. 행묘는 『열반경』에 의거한 오행을 別五行이라 하고 이것을 圓五行으 로 전환하고 있다. 위묘에서는 계위를 설명하는 가운데 특히 十乘觀法 이 설명되어 있다. 이처럼 迹門十妙에서 반드시 觀心으로 마무리되는 것도 그렇지만, 구체적인 觀心的 경전관이 선보이고 있는 “經자에 대 한 해석에서는 觀心이 절정에 달한다. 또 體玄義에서 본체가 실상이라 는 측면에서 실상에 들어가기 위한 방법으로 十乘觀法이 구체적으로 제시되고 있다. 四門 및 別圓으로 구분하며 장통별원 띠敎의 십승관법 이 소상하게 밝혀져 있으므로『摩訶止觀』의 正修章에서도 제대로 밝 히지 못한 십승관법의 전모가 상세하게 드러난다. 또한 마지막으로 자⿻ 相玄義에서는 三種敉相에 대한 觀心으로 三種止觀이 소개되어 있다. 이 三種呚觀이 敎觀兼修라 단적으로 표명되고 있다. 이외에도『법화현 
의』에는 전편에 걸쳐 관심단이 거의 모든 장절에서 설정되어 있고, 게 다가 군데군데에는 심상치 않은 관심론이 소개되어 있다. 더구나 십승 관법에 관한 설명은 오히려 『마하지관』보다도 조직적이기도 하다. 이 것은 종래 교문저작으로 인정되어온 『법화현의』에 관한 시각을 바꿔 놓을 정도로 인상적이다.

그럼에도『법화현의』의 觀心論은 開顯論에 밀려 그동안 별다른 조 명을 받지 못하였다. 『법화현의』전편을 통해 끊임없이 펼쳐지는 觀心 論은 본격적인 수행서인『마하지관』과 비견될 정도이지만 그동안 『법 화현의』는 교문을 위주로 한다는 선입견 때문에 『법화현의』의 수행에 대해서는 그 누구도 제대로 된 눈길조차 주지 않았다. 따라서『법화현 의』에 담겨있는 관문적 가치는 평가절하되고 오직 교상만이 부각되어 『법화현의』는 교문저작이라는 오해만이 난무하고 있는 실정이다. 그 러므로『법화현의』전편을 통해 설해진 觀心을 재고하여 교상문의 대 요라고 하는 『법화현의』에서 관심에 그토록 주력한 이유를 파악함으 로써 천태대사 智顗(538 597)가 조직한 『법화현의』의 교관 규격을 밝 히고자 한다.

\section{2. 七番共解의 觀心}

智顗는 경전을 해석함에 있어서 名·體・宗·用·呚라는 독특한 표 준을 세우고, 그것으로써 경전의 玄義를 설명하고 있다. 이것을 五章 또는 五重玄 및 五重玄義라고 부르는데, 물론 『법화현의』에서도 名· 體·宗・用·敎를 세우고 있다. 『법화현의』에서는 이 五章을 通釋과 別䆁으로 해석하는 가운데1) 通釋인 七番共解는 五章을 총체적으로 해

1)『法華玄義』에서는 名·體·宗·用·呚로 구성된 五重玄義를 공통적인 通釋과 개별 적인 別釋의 두 가지로 해석한다. 전체적인 해석이란 名·體·宗·用·教의 五重을 
석하는 것으로서, 1. 標章, 2. 引證, 3. 生起, 4. 開合, 5. 料簡, 6. 觀心, 7. 會異로 이루어지고,2) 別䆁인 五重各釋은 五章을 각각 개별적으로 해석한 것으로서, 1. 釋名, 2. 顯體, 3. 明宗, 4. 論用, 5. 判呚로 이루어져 있다. 이런 『법화현의』 곳곳에서 강조되는 것은 開顯3)임이 틀림없지 만4) 開顯만큼이나 눈에 띄는 것은 觀心이다.

특히『법화현의』서두에 五重玄義를 나열하여 다섯 가지 마음[五心] 에 상대하면서 五心을 가지고 七番共解를 觀心적으로 풀이하고 있는 대목이 있다.5) 즉 標章은 念心을 쉽게 일으키기 때문이고, 引證은 信 心을 일으키기 때문이며, 生起는 定心을 일으키기 때문이고, 開合·料 簡- 會異는 慧心을 일으키기 때문이며, 觀心은 精進心을 일으키기 때 문이라고 한다. 또한 五心이 세워짐으로써 플⿸𠄌ㄹㅇㅣ 이루어지고, 이 프날 이 五障碍를 물리침으로써 五力을 이루거나 내지는 三解脫門에 들어 갈 수 있게 된다는 것이다.6) 七番共解를 五心으로 이해하여 佛知見을 開示悟入케 한다는 발상은 너무나 독특하고 특이하다. 교리가 교리로

함께 해석하는 것으로서 七番共解라고 하고, 개별적인 해석이란 名·體·宗・用 · 呚의 五重을 각각 해석하는 것으로서 五重各說이라고 한다. 이처럼 五重玄義를 通釋과 別釋으로 해석하는 가운데 五重을 함께 해석하는 七番共解는 五重의 총체적 인 뜻과 그 관계를 드러내는 서론에 해당한다고 할 수 있고, 五重各說은 그 본론에 해당한다고 할 수 있다.

2）智顗說, 『妙法蓮華經玄義』『大正藏』33, p.682a) “就通作七番共解: 一標章, 二引證, 三生起, 四開合, 五料簡, 六觀心, 七會異.”

3) 開顯에 대해서는 七番共解에서 설명되어 있다. 즉 七番共解 중에서는 제7 會異에서 아홉째로 開權顯實을 밝히고 있으며, 五重各說에서는 名玄義에서 本迹十妙를 통해 소상하게 설명되어 있다. 이에 대해서는 이미 논구한 있다.

4) 이에 대해서는 졸고「法華玄義의 開顯論」(『天台學研究』9집)에서 이미 다룬 바 있다.

5）智顗說, 『妙法蓮華經玄義』(『正藏』46, p.682a)；湛然述，『法華玄義釋睵』『大正藏』 46, p.819ab） “初文者結前可知 廣解下生後亦名用章意也 以此七番共解五章穊起五 心 至別解五章 一一無不成於五心塊以七番略解五章 當知廣解五章皆悉具七 是故得 至圓門三脫 入於初住開佛知見 初所以竟”

6）智顗說，『妙法蓮華經玄義』(『正藏』46, p.682a). 
끝나는 것이 아니라 그대로 觀心으로 이어진다는 생각은 너무도 기발 하다. 이러한 태도는 바로 七番共解의 觀心으로 이어진다. 觀心은 七番 共解에 의해 五重玄義를 공통적으로 밝히는 가운데 여섯째로 서술된 것으로서, 『법화현의』의 대표적인 觀心論이라 해도 좋을 것이다. 여기 서는 觀心을 標章·引證·生起·開合・料簡 등 5단으로 설명하고 있 다.7) 七番共解에서 標章에서 料簡까지는 名・體・宗・用・㸚笅의 五重 으로 설명하지만 觀心은 標章부터 料簡까지 五番으로 설명하는 점이 다르다. 이것은 그 중요성에 비추어 철저하게 설명하는 것으로 보인다.

첫째 觀心標章은 법화의 五重을 觀心하는 것을 七番共解 가운데 標 章으로 설명한다.8) 첫째 釋名을 觀心하여 ‘묘법연화경’이란 다섯 글자 인 ‘妙”와 ‘法’과 ‘蓮華”와 ‘經’자가 그대로 마음임을 五章에 준하여 간단 하게 설명하고 있다. 즉 마음이란 허망한 불꽃과 같아서 다만 이름[名] 만 있으니, 그것을 일러 마음이라 하면서 有無로써 생각하고 분별할 수 없으므로 마음을 妙하다고 하며, 妙한 마음은 법도가 있으니 法이 라 하며, 心法은 원인[因]도 아니고 결과[果]도 아닌 理觀과 같지만 因 果를 판별하므로 蓮華라 하고, 一心은 관행을 이루어 여타의 마음도 가르치므로 經이라 한다. 따라서 '妙法蓮華經”란 다섯 자가 그대로 마 음의 이름임을 밝히는 것이다.9) 둘째 마음은 본래 이름이 없고 또한

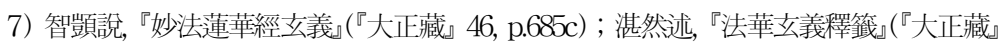
46, p.829a-b) “七番共解已釋五章 會異居後今所未論 故總將第六觀心一章以消前五 令一一文俱入觀門 然須細釋令成妙觀 問若爾 何不以此觀心之文居於第七以消前六 答會異文廣故不越之 所以會異文中自立起觀一門則全悉檀體是於觀 不假附事而爲 理觀”

8）智顗說，『妙法蓮華經玄義』(『大正藏』46, p.685c) “六明觀心者. 從標章至料簡, 悉明觀 心.” ; 湛然述, 『法華玄義釋籤』『大正藏』46, p.829a）“觀心者初示用觀處”

9）智顗說, 『妙法蓮華經玄義』『大正藏』46, p.685c) “心如幻焰, 但有名字, 名之駶心. 適言其有, 不見色質, 適言其無, 復起慮想, 不可以有無思度故, 故名心爲妙. 妙心可軌, 稱之䋧法. 心法非因非果, 能如理觀, 㴧辨因果, 是名蓮華. 由一心成觀, 亦轉敉餘心, 名之虏經. 䆁名竟.”; 湛然述, 『法華玄義釋籤』(大正藏』46, p.829b) “初約標名中言幻 
이름이 없는 것조차 없으니, 마음은 생기지 않는다고 하며 또한 멸하 지 않는다고 하니, '마음이 실상이라[心師實相]'고 하여10) 法華實相의 體를 觀心하는 것을 밝히고, 셋째 ‘처음 관찰하는 것이 원인이 되고 관 찰이 이루어지면 결과가 된다[初觀倸因, 觀成営果]'고 하여,11) 法華一 乘因果의 宗을 觀心하는 것을 밝히고, 넷째 '마음으로 관찰함으로써 잘 못된 깨달음이 일어나지 않는다[以觀心故, 惡覺不起]'고 하여,12) 법화 의 斷疑生信의 用을 觀心하는 것을 밝히고, 다섯째 '心數의 번뇌가 같 거나 다르거나 모두 교화를 받아 교화되니, 이것을 마음으로 관찰한다

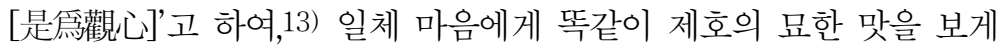
하는 법화교상을 觀心하는 것을 밝히고 있다.

둘째 觀心弓證은 名體宗用敉의 五重을 마음으로 관찰함을 경문을 인용하여 증명하는 것[引證]이다.14) 첫째 '묘법연화경’란 다섯 글자의

焰者幻焰之名通於偏圓 如二十五三昧中有如幻三昧仍義通圓別 今從圓說一心三幻 破一心三惑 理惑體一境智如如 適言下觀法 心性觀之但有名字 言有則一念都無 沉有 十界質像也 言無則復起三千慮想沉一界念慮耶 不可以此有無思故 則一念心中道冷 然 故知心是妙也 妙師三千 三千師法 法故三軌 故云可軌 此之心法非因非果 此擧因 果所依之體 能如理觀此語能取因果之觀故 得名爲體家之宗 用者但是宗體功能 因華 果蓮可以意得 是故名中本含三義由一心等者 研一刹那朁成觀已 師以此觀復觀後心 後心成觀所復成能 後後相續名㸚餘心 經是被下之呚 故觀下惑名經”

10）智顗說, 『妙法蓮華經玄義』(大正藏』46, p.685c) “心本無名, 亦無無名, 心名不生, 亦復不滅, 心㴧實相.” ; 湛然述, 『法華玄義釋籤』『大正藏』46, p.829b) “次別約體中 心本等者 秖是實相雙非有無 雙非生隇轉釋有無”

11）智顗說, 『妙法蓮華經玄義』『大正藏』46, p.685c) “初觀质因; 觀成営果.” ; 湛然述, 『法華玄義釋賳』(『大正藏』46, p.829b) “初觀下宗也”

12）智顗說, 『妙法蓮華經玄義』(大正藏』46, p.685c) “以觀心故, 惡覺不起” ; 湛然述, 『法華立義釋籤』『大正藏』46, p.829b) “惡覺之名不局於淺 不起之相意實在深 故得 觀心爲今經用”

13）智顗說, 『妙法蓮華經玄義(『大正藏』46, p.685c) “心數塵勞, 若同若異, 皆被化而轉, 是爲觀心. 標五章竟” ; 湛然述, 『法華玄義釋籤』『大正藏』46, p.829b) “敎相分別故 云同異 分別此呚無不會實故云而轉”

14）智顗說, 『妙法蓮華經玄義（『大正藏』46, p.685c) “觀心引證者. 釋論云：“一陰名色, 四陰名名.”心但是名也。大經云 : “能觀心性, 名営上定”上定者, 第一義定, 證心是體. 大經云：“夫有心者, 皆當得三菩提.”心是宗也. 遺教云：“制心一虛, 無事不辨.” 
명칭이 마음의 명칭임을, “한 음[一陰]을 色이라 하고 네 음[밋⿱⼆ㅡㄱ을 名 이라 한다.”15)고 하는 『대지도론』의 논문으로, 둘째 법화의 본체가 마 음의 본체임을, “심성을 관찰하는 것을 上定이라 한다.”16)고 하는 『대 반열반경』의 경문으로, 셋째 법화의 종요가 마음의 종요임을, "대저 마 음이 있는 자는 모두 삼보리를 얻는다.” ${ }^{17)}$ 는 『대반열반경』의 경문으 로, 넷째 법화의 역용이 마음의 역용임을, "마음 한 곳을 다스리면 무 사하고 논란이 없다.”18)는 『유교경』의 경문으로, 다섯째 법화의 교상 이 마음의 교상임을, “三界에 다른 법이 없고 오직 一心이 지을 뿐이 다.”19)고 하는 대지도론』의 논문으로 인용하여 증명하고 있다.

셋째 觀心生起란 법화의 五重이 마음의 五重임을 生起로 밝히고 있 다.20) ‘妙法蓮華經”의 명칭을 마음으로 관찰하면 마음으로써 마음을

心是用也. 釋論云 : “三界無別法, 唯是一心作”, 心能地獄, 心能天堂, 心能凡夫, 心能 賢聖. 覺觀心是語本, 以心分別於心, 證心是敎相也.” ; 湛然述, 『法華立義釋籤』『大 正藏』46, p.829b) “不得率爾從近而解”

15）『大智度論』卷5 初品中菩隡功德釋論」第10 “是識共生無色四陰及是所住色, 是名 名色” (『大正藏』25, p.100b. 高麗大藏經 K.549 V.14, p.547a)；怣65 ‘諸波羅蜜品」 第44 “所謂名色, 四大及造色色所攝, 受等四衆名所攝” (p.518c. 高麗大藏經 K.549 V.14, p.1148c).

16）『大般涅槃經』卷25「師子吼菩薩品』第23之1 “佛性者名第一義空, 第一義空名爲智 慧” (大正藏 12, p.767c. 高麗大藏經 K.1403, V.38, p.960a). “一切衆生具足三定謂上, 中, 下. 上者, 謂佛性也. 以是故言, 一切衆生悉有佛性. 中者, 一切衆生具足初樿. 有因緣時, 則能修舶; 若無因緣, 則不能修” (『大正藏』12, p.769b. 高麗大藏經 K.1403, V.38, p.962b).

17）『大般涅槃經』卷3(宋代沙門慧嚴等依泥洹經加之)「純陀品」上 “云夫有心者 皆當 作佛 未來當得常樂我淨” (『大正藏』38, p.57a). 怣11 “夫有心者 悉未來如來 四依開 士唒如如來”(p.102a), 『妙法蓮華經文句』卷7 “夫有心者 皆當作佛 師法身種” ( 大正 藏』34, p.94c).

18）『佛垂般涅槃略說敎誡經』（後秦龜茲國三藏鳥摩羅什奉 詔譯）“制之一處, 無事不辦, 是故比丘, 當勤精進折伏其心” (『大正藏』12, p.1111a).『佛遺敉經論疏節要』(姚秦 三藏法師鳩摩羅什 譯/晉水沙門淨源 節要/雲棲沙門袾宏 補註) “制之於心, 則四分 差別自然休息” (大正藏 40, p.849b).

19）『大智度論』卷29『初品中迴向釋論」第45 “三界所有皆心所作” ( 大正藏』 $25, \mathrm{p} .276 \mathrm{~b}$. 高麗大藏經 K.549 V.14, p.794c), 怣35 “是法無有別異” p. 315. 高麗大藏經 K.549 V.14, p.859b). 
관찰하는 마음의 名이고, 법화의 실상체를 마음으로 관찰하면 관찰하 는 마음[能觀心]으로 보이는 경계[所觀境]가 있는 마음의 體이며, 법화 의 一乘因果用을 마음으로 관찰하면 관찰로써 경계와 계합하기에 因

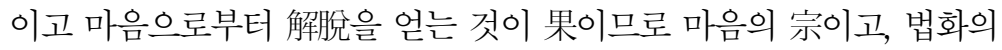
斷疑生信의 宗을 마음으로 관찰하면 일심이 解脱을 얻으면 일체수로 하여금 모두 解脫케 하는 마음의 用이며, 법화의 교상을 마음으로 관 찰하면 心王과 心數가 같이 일어나는 것과 한 쪽만 일어나는 것을 분 별하는 마음의 㸚相이라고 한다.

넷째 觀心開合이란 五重을 觀心하는 것을 七番共解 가운데 열고 닫 는 것[開合]으로 밝히는 것인데, 특히 십이인연으로 개합하는 것이 주 목된다.21) 법화의 명칭을 마음으로 관찰하면 마음은 십이인연이므로 마음의 명칭[心名, 心總]이고, 법화의 體를 마음으로 관찰하면 십이인 연 가운데 일곱 가지 苦心은 法身으로서 마음의 본체[心體]이며, 법화

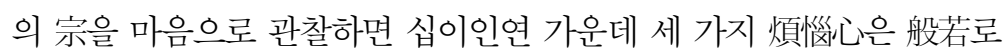
서 마음의 종요[心宗]이고, 법화의 用을 마음으로 관찰하면 십이인연 가운데 두 가지 業心은 解脱로서 마음의 역용[心用]이며, 법화의 교상 을 마음으로 관찰하면 十二因緣을 마음이 생겨나는 것으로 분별하면

20）智顗說, 『妙法蓮華經玄義（『大正藏』46, p.685c) “觀心生起者. 以心觀心, 由能觀心, 有所觀境, 以觀契境故, 從心得解脫故. 若一心得解脫, 能令一切數, 皆得解脫故. 分別 心王心數，同起偏起等，師是教相故.” ; 湛然述，『法華玄義釋䈅』『大正藏』46, p. $829 \mathrm{~b}-\mathrm{c}$ ) “次約生起中以心觀心名也 境體也 觀契因也 得脫果也 此因果宗也 令餘 亦脫用也 分別王數是敎相者 心覞是妙王數亦妙 妙而分別故屬敉相”

21）智顗說, 『妙法蓮華經玄義』『大正藏』46, pp.685c-686a) “觀心開合者. 心是諸法之 本, 心師總也. 別說有三種心. 煩惱心是三支, 若果心是七支, 業心是二支. 苦心鄎法 身, 是心體, 煩恦心㓷般若, 是心宗, 業心㓷解脫, 是心用, 㓷開心爲三也. 分別十二因 緣心生, 節有六道差降, 分別心滅, 㴧有四聖高下, 是爲教相, 兼於開合也.” ; 湛然述, 『法華玄義釋籤』(『大正藏』46, p.829c) “次約開合中約十二緣一念爲總 別秜三道者 師十界三道 以下文分別約十界故 分別文中言敎相兼於開合者 秪此敎相一文兼前 開合約分別邊名爲敎相 秖一生滅名之爲合 離為十界名之爲開” 
六道의 차등이 있고 마음이 소멸하는 것으로 분별하면 미ㅁㅓㅗㅇㅢ 높고 낮 은 차별이 있으므로 마음의 教相이라고 한다.

다섯째 觀心料簡이란 마음으로 관찰하는 것을 헤아려 가리는 것으 로서 특히 根性의 不同을 분별하고 있다. 『大智度論。에서, 부처님은 信 行人을 위해서는 나무로써 비유하고, 法行人을 위해서는 몸으로써 비 유하는 것을 가지고 文字人을 위하여 교리에 맞추어 해석하고 쏯ㅁㅁㅅㅅㅅ 을 위하여 마음으로 관찰하여 해석한다고 하면서 본격적인 料簡을 시 도하고 있다. 먼저 多聞과 智慧에 대하여 『大智度論』에서 평가하는 네 가지 경우를 들고 있다.22) 대지도론』에서 智慧와 多聞을 네 가지 경 우로 구별한 것을 예로 들면서 많이 듣고 지혜가 뛰어난 것이야말로 가장 바람직하다고 보면서『화엄경』과 『법화경』을 인용하여 듣는 데 에만 치우친 과실과 관찰하는 데에만 치우친 과실을 구체적으로 들고 있다.23) 그리하여 빈궁함과 증상만을 면하기 위해 三觀과 츨ㄹ을 닦아 야 한다고 그 방법을 제시하고 있다.24) 文字法師의 빈궁함을 벗어나기

22）智顗說, 『妙法蓮華經玄義』『大正藏』46, p.686a) “文論作四句評：有慧無多聞, 是不 知實相, 譬如大闇中, 有目無所見. 多聞無智慧, 亦不知實相, 譬如大明中, 有燈而無 照. 多聞利智慧, 是所說應受. 無聞無智慧, 是名人身牛. 今使聞慧寁修, 義觀雙擧. 百論有盲跛之譬, 牟子有說行之義. ; 湛然述, 『法華玄義釋籤』『大正藏』46, p.829c) “初文大論四句評聞慧者 具如止觀第一記 此四句中具擧得失 第三句得 餘三並失 次引百論單引兩失 云百論有盲跛等者 百論外人計云 若神無觸身不能到 如盲跛二 人相假能到內 破曰 盲跛二觸二思惟故是故能到 身神無二故不能到今借喻邊相假 能到 不取所計神我及身 今言盲而不跛如有行無解 跛而不盲如有解無行 若解行具 足唒如二全 次引牟子雙失顯得 云牟子有說行之義者 如止觀第一記 以此二喻例釋 大論凹句可知”

23）智顗說, 『妙法蓮華經玄義』『大正藏』46, p.686a) “何者? 視聽馳散, 如風中燈, 照物不 了. 但貴耳入口出, 都不治心, 自是陵人, 增見長非, 把刀自傷, 解育惡道, 由其不習觀 也. 若觀心人, 謂郎心而是, 已則均佛, 都不尋經論, 墮增上慢, 此則抱炬自燒. 行牽惡 道, 由不㞧聞也.” ; 湛然述, 『法華玄義釋籤(『大正藏』 $46, \mathrm{p} .829 \mathrm{c}$ ) “次何者下責失中 以言敎之風吹無室之燈 室如定也 照於理境諸法不了 且略擧一慢應具足諸惑 執妙 敎之刃 傷智照之手 若但暗證觀心之人起增上慢 前是我慢與此中別 抱暗證之炬燒 勝定之手”

24）智顗說, 『妙法蓮華經玄義』『大正藏』46, p.686a)；湛然述，『法華玄義釋䈅』『大正藏 
위한 방도로 觀心法 즉 三觀을 제시하고 있으며,25) 闇登禪師를 훈계하 는 가르침으로 六師을 설하고 있다.26) 특히 六師에 대해서는 간단한 설명을 달고 있다. 그러므로 마음을 닦아 안으로 관찰하니 法財가 있 고, 바르게 믿어 밖에서 들으니 다시는 增上慢이 없게 된다고 하면 서27) “多聞과 智慧가 함께 하면 눈이 지혜롭고 명확하게 들어 이익이 구족하거늘 어찌 관찰하여 이해하지 못하겠느냐”고 반문함으로써 경 문에 치우치거나 삿된 견해에 경도된 이들을 꾸짖고 있다. 呚觀雙修의 측면에서 문자의 법사와 암증의 선사를 지양하고 올바른 교관을 갖도 록 충고하고 있는 것은 觀心段의 교관적 성격을 그대로 반영한다고 하 겠다.

\section{3. 行妙의 圓五行}

다음으로 오중각석으로 해석하는 가운데 적문십묘 중 세 번째 행묘 는 행법을 본격적인 밝히고『법화현의』의 행법체계이다. 행묘가 그대 로 수행체계이기에 그대로 행법론이라 할 수 있고, 원교의 수행론은 그대로 법화의 행법론이라 해도 좋을 것이다. 行妙는 수를 더해가는 행, 차제적인 오행, 차제를 거치지 않는 오행을 자세하게 밝히고 있다. 첫째 수를 더해가는 행은, 일반적인 방법으로 수를 더해가는 행과 가

』46, pp.829c-830a) “若欲下示得爲二 先示 次結 初文先略示”

25) 三觀이란 『瓔珞本業經』에 기초한 從假入空觀 - 從空入假觀 - 中道第一觀으로서, 空觀・假觀・中觀이라 하고 이것을 묶어 空・假 - 中 三觀이라고 한다. 이에 대한 종합적인 연구는 다음 기회로 미루기로 한다. 三觀을 닦아야 실제로 수행이 가능하 기 때문에 이렇게 말한 것이다.

26）智顗說, 『妙法蓮華經玄義』(『正藏』46, p.686a); 湛然述, 『法華玄義釋蛓』『大正藏 』4, p.830a）“次釋六師”

27）智顗說, 『妙法蓮華經玄義(『大正藏』46, p.686a) “眼慧明聞 具足利益, 何得不觀解 耶.” ; 湛然述, 『法華玄義釋籤』『大正藏』46, p.830a) “眼明慧聞隔字爲對 所益蓋廣 何得不以觀解五章之文令眼智具耶” 
르침에 의거하여 수를 더해가는 행을 밝히는 가운데 가르침에 의거하 여 수를 더해가는 행은 장통별원 사교의 행이 있다. 이 가운데 원교의 행은 增數로 하는 가운데 십경과 십승관법에 대하여 명목만 밝히고 있 다. 또 五行에 의거해 본격적으로 行妙를 밝히는데 먼저 차별적인 오 행을 밝히고,28) 다음에 원만한 오행을 밝힌다. 智顗는 圓行을 강조하 여 다음과 같이 밝히고 있다.

원만한 오행이란, 『대반열반경』에서, "또 일행이 있는데 이것은 바로 여래행이다. 이른바 대승대반열반을 말하는 것이다." ${ }^{29)}$ 고 한다. 이 가운 데 대승은 원만한 원인이고, 열반은 원만한 결과이다. 이것을 인용하여 如來行을 나타낸 것이니, 다른 육바라밀 · 통교 - 별교 등의 행을 나타낸 것은 아니다. 앞에서 대승이라 했을지라도 원만하게 움직일 수 없고,

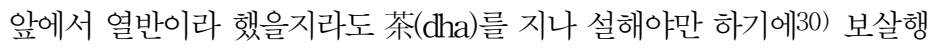

28) 차별적인 행이란, 열반경에서 설한 五行 즉 聖行 · 梵行 · 天行 · 嬰兒行·病行이다. 聖行은 계정혜로서 戒聖行은, 禁戒·清淨戒·善戒의 三戒律儀이고, 定聖行은 첫째 世間禪, 둘째 出世間禪, 셋째 上上禪으로 구분하며, 慧聖行은 四種四諦의 慧로서

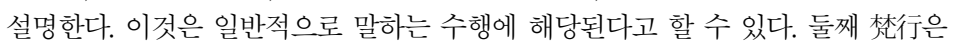
청정한 법으로 중생에게 괴로움을 뽑아 없애주고 즐거움을 주는 것으로서 無緣의 慈悲喜捨이다. 二十五三昧의 무한히 큰 역용을 구족하는데 이때의 자비가 참된 범행이라고 한다. 셋째로 天行은 第一義天으로서 초지 이전을 말한다. 이치에 말미암아 수행을 이루므로 천행이라고 한다. 십지의 지혜를 닦아 十重禁戒로 참된 수행의 지혜를 발한다고 한다. 넷째로 嬰兒行은 복혜가 더욱 증가하면 실상이 가득히 드러나는데 비록 의도적으로 중생을 이롭게 하지 않아도 저절로 冥顯의 두 이익이 있다고 한다. 다섯째 病行은 무연의 대비로부터 일어나는데, 처음에 작은 선을 내면 반드시 병행이 있다고 한다. 번뇌와 함께 하는 쪽을 병행이라 하는데, 중생이 않기에 대비로 마음에 젖어 내가 않는 것이라고 한다.

29）『大般涅槃經』卷11 聖行品」第19之1 “爾時, 佛告迦葉菩薩: 善男子, 菩薩摩訶薩應當 於是般涅槃經, 專心思惟五種之行. 何等爲五? 一者聖行, 二者梵行, 三者天行, 四者 嬰兒行, 五者病行. 善男子, 菩薩摩訶薩常當修百是五種行, 復有一行是如來行. 所謂 大乘大涅槃經” (『大正藏』12, p.673b. 高麗大藏經 K.1403, V.38, p.823b).

30) “茶字門( 入諸法邊竟處故不終不生, 過茶無字可說 何以故. 更無字故, 諸字無礙, 無名亦滅, 不可說不可示不可見不可書” (『大正藏』 8, p.256a. 高麗大藏經 K.3, V.5, p.282a). 『大智度論』卷48「釋四念處品」第19 (『大正藏』 25, p.407c. 高麗大藏經 
은 여래의 일행이라 할 수 없다. 만약 원만한 행이 원만히 십법계를 갖추 면, 一運師一切運이 되기에 대승이라고 한다. 즉 불승을 타기에 여래행 이라고도 한다. 『대지도론』에서, “초발심에서 항상 열반을 관찰하고 도 를 행한다.”31) 고 한 것과 같다. 또한『대품반야경』에서, “초발심에서 행하고 일으키고 닦고 내지 도량에서 좌선하고 또 행하고 일으키고 닦는 다. 궁극적인 경지와 발심은 둘로 구별되지 않는다.”32)고 한 것과 같다. 이것은 모두 여래행의 뜻이다.

『법화경』에 의하여 원만한 오행을 해석하면, 오행은 일심 가운데에 구족하여 결여됨이 없기에 여래행이라 한다. 『법화경』에, '여래의 장엄 으로 스스로를 장엄한다'33)고 하는 것은 원만한 성행이고, '여래의 방' 이란 원만한 범행이고, '여래의 자리’란 원만한 천행이라고 하며, 또 '여 래의 옷'은 두 가지 종류가 있는데, 유화한 것은 원만한 영아행이고, 인 욕은 원만한 병행이라고 한다.34) 이러한 五種行은 하나의 실상행이라

K.549, V.14, p.985c).

31) 『摩訶止觀』卷3 “大論云, 菩隡從初發心常觀涅槃行道” ( 大正藏』46, p.22c). 『大般涅 槃經疏』卷9 “今明圓菩薩從初發心常觀涅槃行道” (『大正藏』38, p.90b).

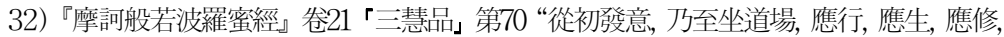
般若波羅蜜” (『大正藏』8, p.373a. 高麗大藏經 K.3, V.5, p.452a). 『大智度論』卷81 r六度品」第68之餘 “從初發心乃至坐道場, 不生矌心奪衆生命, 亦不著二乘, 皆是二 波羅蜜功德故, 離三種心, 迴向阿振多羅三藐三菩提” (『大正藏』25, p.629a. 高麗大 藏經 K.549, V.14, p.1309c)。『大般涅槃經』卷34 「迦葉菩薩品」之4 “發心里竟二不別, 如是二心先心難, 自未得度先度他, 是故我禮初發心, 初發已営人天師, 勝出聲聞及 緣覺, 如是發心過三界, 是故得名最無上” (『大正藏』12, p.838a. 高麗大藏經 K.1403, V.38, p.1061b).

33) 『妙法蓮華經』卷4 “當知, 是人以佛莊嚴而自莊嚴” (『大正藏』9, p.31a . 高麗大藏經 K.116, V.9, p.760c). ; 『大方廣佛華嚴經』卷39 “菩薩發如是心: 我當發大莊嚴, 而自莊嚴, 化度衆生, 皆令成阿㱹多羅三藐三菩提, 以大般涅槃, 而般涅槃. 是䈆菩薩 摩訶薩第二發金剛心, 莊嚴大乘” (『大正藏』9, p.645a).

34）『妙法蓮華經』卷4「法師品」第10 “是善男子, 善女人, 入如來室, 著如來衣, 坐如 來座, 爾乃應爲四衆廣說斯經, 如來室者, 一切衆生中大慈悲心是; 如來衣者, 柔和忍辱心是; 如來座者, 一切法空是, 安住是中, 然後以不懈怠心, 爲諸菩薩 及四衆廣說是法華經” (『大正藏』9, p.31c. 高麗大藏經 K.116, V.9, p.761c). 
고 하면서, 하나는 다섯이 되지 못하고 다섯은 하나가 되지 못하며, 함 께 하는 것도 아니고 떨어진 것도 아니기에 불가사의하여 하나의 오행 이라 한다. 또한 圓行을 境妙에 대하는 가운데 四種十二因緣의 智 行,35) 四種四諦의 智行,36) 七種二諦의 智行,37) 五種三諦의 智行38), 一 實諦의 智行39)으로 설명하고 있다. 즉 원교의 十二因緣, 四諦, 二諦, 三 諦, 一實諦의 智行을 圓五行이라고 하는 것이다. 경묘단에 보이는 六境 가운데 如是境만을 제외하고 五境을 圓의 오행으로 설명하는 것이다. 또 원오행은 구체적으로 如來三軌로 설명을 그치면서『열반경』에 나 와 있는 오행을 원교로 전환해 보이고 있을 뿐이다. 그런 가운데 계정 혜 삼행이 성행에서 나오고 있을 뿐 智顗가 스스로 조직한 십승관법의 체계는 전혀 언급되지 않고 있다. 『열반경』에 나오는 오행을 가지고 원교의 오행으로 전환한 것이야말로 입顊의 행에 대한 법화해석이라 해도 좋을 것이다.

35）智顗說, 『妙法蓮華經玄義』(『大正藏』33,p.726a) “又圓五行, 師是四種十二因緣智 行. 不思議識名色等淸淨, 師戒聖行, 行有等淸淨, 郎定聖行, 無明愛等淸淨, 郎慧聖

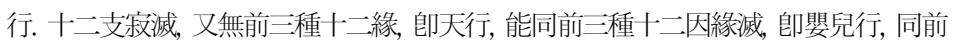
十二因緣生, 師病行.”

36）智顗說, 『妙法蓮華經玄義』(『大正藏』33, p.726a）又是四種四諦智行. 無作之道, 師戒定慧聖行, 無作之滅, 郎天行. 慈悲拔苦拔四種苦, 與四種樂, 師梵行, 直悲師病 行, 直慈師嬰兒行.

37）智顗說, 『妙法蓮華經玄義』(『大正藏』33, p.726a) 又是七種二諦智行. 圓眞方便, 師是 聖行, 圓顛之理, 師是天行, 悲七俗慈七善師梵行, 同七俗師病行, 同七䢐師嬰兒行.

38）智顗說, 『妙法蓮華經玄義』『大正藏』33, p.726a) 又是五種三諦智行. 俗諦中善, 是戒 聖行, 眞諦中樿, 是定聖行, 眞諦慧㓷慧聖行, 中諦是天行, 拔五俗苦與五眞中樂, 是梵 行, 同五俗是病行, 同五眞中, 是嬰兒行.

39）智顗說, 『妙法蓮華經玄義』(大正藏』33, p.726a) 又是一實諦智行. 一實諦有道共戒 定慧, 䄱聖行, 一實境師天行, 同體慈悲合說, 㴧梵行, 各說師病行 - 嬰兒行. 


\section{4. 位妙의 最實位十心}

다음으로 적문십묘 가운데 네 번째 位妙에는 구체적인 수행론이 담 겨져 있다. 계위를 중심으로 하여 구체적인 행법이 상세하게 논구되어 있다.40) 位妙는 『법화경』약초유품에 나오는 세 가지 풀의 계위[三草 位]와 두 가지 나무의 계위[二木位], 하나의 참된 계위[一實位] 등 여섯 계위로 분류하고 있다.41) 작은 약초와 중간 약초와 큰 약초는 장교 계 위이고, 작은 나무는 통교의 계위이며, 큰 나무는 별교의 계위이고, 가 장 진실한 것은 원교의 계위라고 한다.42) 이렇게 계위를 밝히는 가운

40)『법화현의』에는 오중현의 가운데 체현의에서 십승관법에 대해 비교적 상세하게 설명하고 있다. 따라서『법화현의』의 교리적 성격상 십승관법이 설명되고 있는 것은 의외이다. 실상에 들어가기 위한 방법으로 사교마다 有門觀으로 설명하고 있다. 空門觀・亦有亦空觀・非有非空觀의 삼문의 관법이 생략되고 있다. 장교의 십승관법은 비교적 자세하게 無常·無我·苦・空으로 또는 眞諦로 해석되고 있으 며, 통교의 십승관법은 아주 간략하게 一切法空 또는 색에 즉한 진제로 설명되어 있으며, 별교의 십승관법은 비교적 차제로 생사·법성 - 중도로 설명되어 있고, 원교의 십승관법은 생사의 색에 즉한 법성의 색 또는 법성의 색에 즉한 中諦로 설명되어 있다. 또한 장통병원의 사교로 설명하는 방법은 『마하지관』의 태도와는 사뭇 다르다. 이것을 통하여 사교의 십승관법에 관한 구분을 명확하게 알 수 있다. 또한 無門을 통해 십승관법을 설명하는 『마하지관』과는 달리, 삼장의 유문관 으로부터 통교의 유문관 및 별교의 유문관 그리고 원교의 유문관을 설명하고 있는 것도 아주 특이하다고 할 것이다. 특히『法華立義』에서 十乘觀法을 有門으로 밝히고 있는 것은 『摩訶止觀 에서 無生門으로 설명하는 것과 대비된다고 할 수 있다.

41）『妙法蓮華經』卷3「藥草喻品」第5 “轉輪聖王, 釋梵諸王, 是小藥草, 知無漏法, 能 得涅槃, 起六神通, 及得三明, 獨處山林, 常行禪定, 得緣覺證, 是中藥草, 求 世尊處, “我當作佛” 行精進定，是上藥草” (『大正藏』9, p.20a)。“諸佛子專心佛 道, 常行慈悲，自知作佛，決定無疑，是名小樹。安住神通，轉不退輪，度無量 億, 百千衆生，如是菩薩 名爲大樹” (『大正藏』9, p.20a. 高麗大藏經 K.116, V.9, p.747b)

42）智顗說,『妙法蓮華經玄義』『大正藏』33,p.726b）今藥草喻品，但明六位，文云： “轉輪聖王釋梵諸王, 是小藥草. 知無漏法, 能得涅槃, 獨處山林, 得緣覺證, 是中藥草. 求世尊處, 我當作佛, 行精進定, 是上藥草. 又諸佛子, 專心佛道, 常行慈悲, 自知作佛, 決定無疑, 是名小樹. 安住秆通, 轉不退輪, 度無量億百千衆生, 是名大樹.”追取長行 
데 원교를 十信 - 十住 - 十行 - 十迴向 - 十地 - 等覺 - 妙晞으로 설명하 고 있다.43)

원교의 수행이란 一行이 一切行이다.44) 간략하게 말하면 열 가지가 된 다. $\cdots$ 이렇게 하여 열 가지 마음[十心을 성취한다.45) 요컨대 그 마음이 순간순간마다 모두 모든 바라밀[諸波羅蜜]과 相應한다. 이것을 원교의 初隨喜品位라고 한다.46) // 수행자의 원교에 대한 믿음[圓信]이 비로소 생겨나면 잘 길러야 한다. 만약 일[事]에 관계하여 어지럽게 움직이면 도의 싹[道芽]을 부수고 없앤다. 오직 안으로 理觀을 닦고, 밖으로 대승 경전을 受持하고 讀誦하면 듣는 것[聞]에 관찰[觀]을 돕는 힘이 있다. 안팍으로 서로 의지하여 원교의 믿음[圓信]이 더욱 더 밝아지면 十心이 견고해진다.47) $\cdots$ 들음에 큰 이익이 있다는 것은 그 뜻이 여기에 있다. 이것을 第二品位라고 한다.48) // 수행자의 내관(队觀)이 더욱 더 강하게 바뀌어 밖에서 도와 더욱 더해진다. 원교의 이해[圓解를 마음으로 품고 커다란 서원[弘誓]으로 젖어 움직이며, 다시 설법을 더하여 여실하게

中, “一地所生, 一雨所潤.” 及後文云 : “今當爲汝, 說最實事.” 以爲第六位也. 前三義 是藏中位，小樹是通位，大樹是別位，最實事是圓位也.

43）智顗說, 『妙法蓮華經玄義』『大正藏』33, p.733a) 還約七種以明階位, 謂十信 ・十 住・十行・十迴向・十地・等覺・妙晞.

44) 智顗說, 『妙法蓮華經玄義』(『大正藏』33, p.733a) 欲開此心, 而修圓行. 圓行者 : 一行一切行.

45）智顗說, 『妙法蓮華經玄義』 『大正藏』33, p.733a) 略言爲十. 謂識一念, 平等具足, 不可思議 ; 傷己昏沈, 慈及一切; 又知此心, 常寂常照; 用寂照心破一切法, 師空師假 師中 ; 又識一心諸心, 若通若塞; 能於此心, 具足道品, 向菩提路; 又解此心, 正助之法 ; 又識己心及凡聖心; 又安心不動, 不隋 - 不退・不散; 雖識一心無量功德, 不生染 著. 十心成就.

46）智顗說, 『妙法蓮華經玄義』(『大正藏』33, p.733a) 擧要言之, 其心念念, 悉與諸波羅蜜 相應. 是名圓敉初隨喜品位.

47）智顗說, 『妙法蓮華經玄義』『大正藏』33, p.733a-b) 行者圓信始生, 善須將養. 若涉事 紛動, 令道芽破敗. 唯得內修理觀, 外則受持讀誦大乘經典, 聞有助觀之力. 內外相藉, 圓信轉明, 十心堅固.

48）智顗說, 『妙法蓮華經玄義』『大正藏』33,p.733b) 論云：“於實名了因, 於餘名生因. 福不趣菩提, 二能趣菩提.”聞有巨六，意在於此. 是名第二品位. 


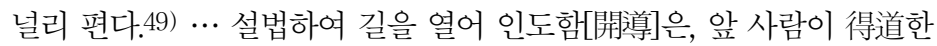
모든 인연이니, 교화하고 제도하는 공덕[化功]이 자기에게로 돌아와 十 心이 세 배가 되어 더욱 더 밝아진다. 이것을 第三品位라고 한다.50) // 위에서는 이전의 계위에서 觀心을 잘 성숙시켰지만 아직 구체적인 사물 [事]에 미치는 데에는 겨를이 없다. 지금은 正觀이 점점 밝아져 아울러 중생을 이롭게 함[利物]을 겸한다. 적은 보시로써 虛空法界와 같게 되고, 일체법을 보시[相로 향하게 하며, 보시[檀를 法界로 삼는다.51) $\cdots$ 그런 즉 理觀을 본령으로 삼고, 事行을 부수적인 것으로 삼는다. 그러므로 “겸하여 布施를 행한다.”52)고 한다.53) 밖으로 드러난 사물[事]의 福으로 이치[理]를 도우면 十心이 더욱 성해진다. 이것을 第四品位라고 한다.54) // 수행인의 圓觀이 점점 무르익어 사물[事]과 이치[理]를 융합하면, 사 물을 두루 하는 데에도 이치[理]를 방해하지 않고 이치[理]에 있어서도 사물[事]과 떨어져 있는 것도 아니다. 그러므로 빠짐없이 六度을 갖추어 행한다.55) ... 佛知見을 갖추어 해석하면, 正觀에 있어서 마치 불에 땔나 무를 더한 것과 같다. 이것이 第五品位이다.56) $\cdots / /$ 첫째, 十信位를 밝힌 다. 처음에 원교를 들음[圓聞]으로써 원교의 믿음[圓信]을 일으키고, 圓

49）智顗說, 『妙法蓮華經玄義』(『正藏』33, p.733b) 行者, 內觀轉强, 外資又著. 圓解在 懷，弘誓熏動，更加說法，如實演布.

50) 智顗說, 『妙法蓮華經玄義』(『大正藏』33, p.733b) 說法開導, 是前人, 得道全因緣, 化功歸己, 十心則三倍轉明. 是名第三品位.

51）智顗說, 『妙法蓮華經玄義』『大正藏』33,p.733b) 上來前熟觀心, 未遑涉事. 今正觀稍 明, 師傍兼利物. 能以少施, 與虛空法界等, 使一切法趣檀, 檀爲法界.

52）『妙法蓮華經』卷5「分別功德品」第17 “如來滅後, 若有受持,讀誦, 爲他人說, 若自 書，若教人書，供養經卷，不須復起塔寺，及造僧坊，供養衆僧，沉復有人能持是 經, 萧行布施, 持戒, 忍辱, 精進, 一心, 智慧, 其德最勝, 無量無邊” ( p.45c . 高麗大藏經 K.116, V.9, p.779a).

53）智顗說,『妙法蓮華經玄義』『大正藏』33, p.733b) 此則理觀爲正, 事行爲傍. 故言兼行 布施.

54）智顗說, 『妙法蓮華經玄義』『大正藏』33, p.733b) 事福資理, 則十心彌盛. 是名第四品 位.

55）智顗說,『妙法蓮華經玄義』『大正藏』33, p.733b) 行人圓觀稍熟, 事理欲融, 涉事不妨 理, 在理不隔事. 故具行六度.

56）智顗說，『妙法蓮華經玄義』『大正藏』33，p.733b）具足解釋佛之知見，而於正觀， 如火益薪. 此是第五品位. 
敉의 행[圓行]을 닦아 교묘하게 잘 증익하여, 원교의 행으로 하여금 다섯 배로 깊고 밝게 한다. 이 원교의 행으로 인하여 원교의 계위[圓位]에 들어가게 된다.57) $\cdots$ 이것을 十信位에 들어간다고 한다. // 일곱째로 妙覺의 지위[地]를 밝히면, 究竞解脱, 無上佛智이다...이것은 앞 十觀成 乘의 원교의 究極究竟으로 부처에게 있다.58)

十信 이전에 五品位를 밝히는데,59) 초수희품에서 십승관법에 대하

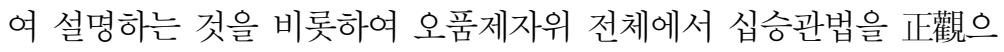
로 보고 있으며, 그리고 십신위에서도 십승관법이 중점적으로 설명되 고, 마지막으로 묘각위에서 십관성승이라 하여 마무리하고 있다. 이것 은 십승관법이 묘각위에 성취됨을 분명히 하고 있다. 이와 같이 位妙 는 십승관법이 그 본령으로 되어 있다. 오품제자위로부터 마지막 묘각 위에 이르기까지 행법으로 正觀으로 십승관법을 제시하고 있으므로 십승관법은 위묘에서는 관심법의 正觀임은 두말할 나위가 없다. 이것 은 행묘에서『열반경』의 오행을 근본하는 것과는 적지않은 차이를 보 인다. 행묘에서 보인 오행은 경전 그대로의 행법이라면 위묘에서 보이 는 십승관법은 智顗가 새로 구성한 관법이라는 점에서 대조를 보인다 고 할 수 있다.

57）智顗說, 『妙法蓮華經玄義』(『大正藏』33, p.733c) 一明十信位者, 初以圓聞, 能起圓信, 修於圓行, 善巧增益, 令此圓行五倍深明. 因此圓行, 得入圓位.

58）智顗說，『妙法蓮華經玄義』(『正藏』33,p.734c) 七明妙覺地者, 究竟解脱, 無上佛智. 故言無所斷者, 名無上士. 此師三德不縱不橫, 究竟後心大涅槃也. 一切大, 理大・誓 願大 $\cdot$ 莊嚴大 $\cdot$ 智斷大 $\cdot$ 徧知大 $\cdot$ 道大 $\cdot$ 用大 $\cdot$ 權實大 $\cdot$ 利益大 $\cdot$ 無住大. 師是 前十觀成乘圓極, 究竟在於佛. 過茶無字可說. 云云. 故盧舍那佛, 名妥淨滿. 一切皆滿 也.

59）智顗說, 『妙法蓮華經玄義』『大正藏』33, p.733a）今於十信之前, 更明五品之位. 云云. 


\section{5. 經’字 觀心}

『法華玄義』에서는 경전 제목의 제일 뒤에 있는 "經자에 대한 관심 석이 아주 주목된다. "經자에 대해 五重玄義 가운데 名玄義에서 해석 하고 있다. "經자를 해석함에 있어서 '妙法”만큼 비중이 있는 것은 아니 지만 경전에 관한 구체적인 관심이 담겨져 있다. 『法華玄義』에서는 번 역하지 않는 無翻과 번역하는 有鄱으로 풀이한 다음에 두 가지를 조화 시키며 마지막으로 歷法 즉 법을 거쳐 관심을 하고 있다. 첫째, 無䧽觀 은 마음에 모든 心數 등을 포함한다는 전제 아래 마음에 담겨져 있는 法本,60) 微發,61) 涌泉,62) 結鬘63) 繩墨64)의 뜻을 언어[語]와 수행[行] 과 이치[理로 관심토록 한다. 둘째, 有翻萑筧은 마음으로부터 연유한다 는 뜻에서 經65) 契,66) 法本,67) 線,68) 善語敉69)를 언어와 수행과 이치

60）智顗說, 『妙法蓮華經玄義』(『正藏』33, p.778b) “心是法本者. 釋論云: “一切世間中 無不從心造.” 無心無思覺, 無思覺無言語. 當知, 心㴧語本. 心是行本者. 大集云: “心行 大行遍行” 心是思數, 思數屬行陰, 諸行由思心而立, 故心爲行本. 心是理本者, 若無 心, 理與誰合. 以初心研理, 恍恍將悟, 稍入相似, 則證眞實, 是爲理本.”

61）智顗說，『妙法蓮華經玄義』『大正藏』33,p.778b）“心含微發者. 初刹那微微而有, 次心若存若亡, 次漸增長, 後則決定, 暢心而發口, 是語微發, 初心習行, 行猶微弱. 次少樹立, 後成大行, 師行微發. 初觀心不見心理, 更修䯮鬅, 乃至相似眞實師理微 發.”

62）智顗說, 『妙法蓮華經玄義』『大正藏』33, p.778b) “心含涌泉者. 心具諸法, 障故不流. 如土石壓泉, 去壅涌溜. 若不觀心, 心闇不明, 所說不長. 若觀心明徹, 則宣辩無方, 流㵋難盡. 豈非語涌泉. 若不觀心, 行則有間, 以觀心故, 念念相續, 翻六蔽成六度, 六度攝一切行, 是行涌泉. 若能觀心, 如利鑟斨地, 磐石沙函, 理水声澄, 滔滔無竭, 師義涌泉.”

63）智顗說, 『妙法蓮華經玄義』『大正藏』33, p.778b) “心含結鬘者. 觀念不謬, 得一聞持, 穿文無失. 觀心得定共力, 穿行無失. 觀心得道共力, 穿義無失. 又觀心得定慧, 嚴顯法 身, 此皆可解."

64）智顗說, 『妙法蓮華經玄義』『大正藏』33, p.778b) “支心是繩墨. 若觀心得正語, 難邪 倒說, 觀心正則勉邪行, 心無見著則入正理, 事行如繩理行如墨, 彈愛見木成正法器 也. 是爲心經多含, 略示十五義. 云云.”

65）智顗說, 『妙法蓮華經玄義』(『正藏』33, p.778c) “二類有眽明觀者. 心㴧是由, 三義 由心, 一切語言, 由覺觀心, 一切語行, 由於思心, 一切義理, 由於慧心 經云: “諸佛解 
로 관심토록 한다.70) 셋째 有無和融觀은 생략하고 있으며,71) 넷째 법 에 거쳐 마음을 관찰하는 歷法觀心은 마음이 일체 언어의 근본, 수행 의 근본, 이치의 근본이므로 이것을 관심토록 하고 있다.72) 경자를 해 석하는 가운데 관심으로 보인 이 단은 경을 어떻게 관심해야 하는가에 대한 구체적인 사례를 극명하게 보인 것이다. 네 가지로 관심을 설명 하는 가운데 일체법이 마음이라고 하면서, "일체심에 두루 하여 經이 아닌 것이 없다.”73)고 하는 것으로 마무리를 짓고 있다. 즉 경전이 단 지 경전이 아니라 일체 모든 것이 바로 경전이고 일체 모든 것은 바로 마음이라는 것이다. 그렇다고 한다면 경전은 바로 내 마음이고 내 마 음이야말로 경전이라는 뜻으로 통한다면, 종래의 경전관과는 전혀 그 각도를 달리한다고 할 수 있을 것이다. 이와 같이 경자를 통해 관심에

脫, 當於衆生, 心行中求.”心是經緯, 以覺爲經, 以觀爲緯, 織成言語. 又慧行心爲經, 行行心爲緯, 織成衆行, 心堅緣理烝經, 心橫緣理爲緯. 云云."

66）智顗說, 『妙法蓮華經玄義』(『正藏』33, p.778c) “文㴧是契, 觀慧契境, 是契緣, 契樂欲心爲契呚, 契便宜對治心為契行, 契第一義心契理.”

67）智顗說，『妙法蓮華經玄義』『大正藏』33, p.778c）“心絾法本.”

68）智顗說，『妙法蓮華經玄義』『大正藏』33，p.778c）“心絾線者，如前. 云云.”

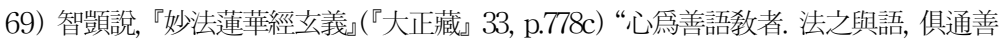
惡, 今以善法善語定之, 心之與觀, 亦通善惡, 今以善心善觀定之 師是善語敉, 善行善 理敎, 心具三義.”

70) 智顗說, 『妙法蓮華經玄義』(『大正藏』33, p.778c) “心是可軌者. 若無觀則無規矩, 以觀正心王. 心王正故, 心數亦正, 行理亦爾. 心王契理敎亦契理, 故名可軌也. 心常 者, 心性常定, 唒如虛空, 誰能破者. 又惡覺不能壞善覺, 邪行不干正行, 邪理不壞正 理, 故心名常. 隨諸事釋, 一一向心爲觀, 觀慧彌成, 於事無乘. 如火益薪, 事理無失. 師文字無文字，不捨文字，而別作觀者也.”

71）智顗說，『妙法蓮華經玄義』(『正藏』33, p.778c) “三類和融有無明觀者, 可解. 云云.”

72) 智顗說, 『妙法蓮華經玄義 (『大正藏』33, p.778c) “觀一心㴧三心, 以此三心, 歷一切 心, 歷一切法, 何心何法, 而不一三. 一切法趣此心, 一切心趣此法. 如此觀心, 爲一切 語本行本理本. 有眬五義, 無粮五義, 一一於心, 解釋無滯, 遍一切心, 無不是經. 大意 可領, 不俟多記也.”

73）智顗說，『妙法蓮華經玄義』大正藏』33, p. 78c) “觀一心㓥三心, 以此三心, 歷一切心, 歷一切法, 何心何法, 而不一三. 一切法趣此心, 一切心趣此法. 如此觀心, 萹一切語本 行本理本. 有㼑五義, 無眽五義, 一一於心, 解釋無滯, 遍一切心, 無不是經. 大意可領, 不俟多記也.” 
대한 사례를 구체적으로 보여주고 있다.

\section{6. 體玄義의 十乘觀法}

법화의 체현의를 설명하는 가운데 뜻밖에 실상관이 그 중심에 서있 다. 더구나 일곱 조항으로 체를 해석하는 가운데 네 번째 체인 실상에 들어가는 문을 통해 상세하게 四敉의 관문을 설명하는 것이다. 즉 入 門觀에서 十乘觀法을 가지고 사교의 觀門에 대하여 자세한 설명을 가 하고 있는 것이 그것인데, 의외로 觀門이 바로 體玄義에서 발휘되고 있는 것을 확인할 수 있다. 특히 그중에서도 원교의 十乘觀法이 강조 되고 있는 것은 주의해야 한다. 體實相에 들어가는 문을 밝히는 가운 데 법문에 들어가는 관법을 설명하는 중 입문관으로서 장통별원 사교

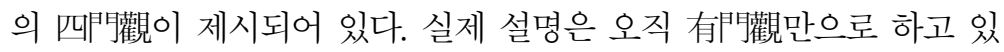

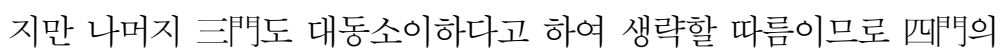
구조임은 두말할 필요도 없다. 그리하여 원교의 사문을 설명하고 有門 에 의한 관법으로74) 십승관법의 성격을 명확하게 밝히고 있다.75) 원

74）智顗說，『妙法蓮華經玄義』(大正藏』33, p.789c) “二明入實觀者.上已知四圓門， 今依有門修觀. 觀則爲十. 云云.”

75) “저 유문 가운데는 信行과 法行을 갖추고 있다. 信行은 설법을 듣고 깨치면 그 마음이 빨리 이롭게 되지만 도를 얻는 방법은 사람에게 나타내기 어렵다. 또 法行의 관문에 맞추면, 열 가지 뜻이다.”고 하는 것처럼 유문에 信行과 法行을 갖추고 있다고 하여, 이미 아함에서 나오는 신행과 법행에 대한 구별을 智顗는 이미 파악한 것으로 보인다. “二略示入門觀者. 先明三藏有門觀. 彼有門中具於信法, 信行聞說師悟, 此心疾利, 得道方法難可示人. 且約法行觀門, 師爲十意 : 一識所觀境, 二眞正發心, 三遵修淨慧, 四能破法遍, 五善知識通知塞, 六善用道品, 七善用對治, 八善知次位, 九善能安忍, 十者法愛不生” (『大正藏』33, p.785b-c). 따라서『마하지 관』에서 수행의 본령으로 다루어지는 ⿱一⿻上丨俢는 법행인을 위해 맞추어진 것임을 알 수 있다. 또한『아비담론』 가운데 이 열 가지 뜻이 갖추어져 있다고 하면서 명확하게 아비달마에도 십승관법이 있음을 명확히 하고 있다. 그렇지만 그 경문이 군데군데 흩어져 있기에 논사가 설령 도를 행하려 해도 무엇에 의하여 닦아야 
앞 십이인연의 思議門에 대하여 不思議竟이라고 한다. 부사의경은 二實

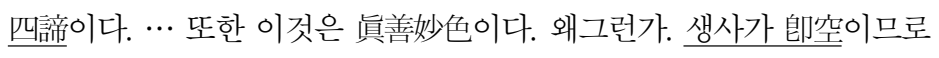
眞이라 하고, 생사가 師假이므로 善이라 하고, 생사가 師中이므로 妙라 고 한다. 이것을 有門의 불가사의경이라 한다.77) // 두 번째는, 참되고 바른 마음을 일으키는 것이다. 일체 중생이 대열반이니, 어찌 전도되어 즐거움을 괴로움으로 삼겠는가. 일체 번뇌는 보리이니, 어찌 어리석음으 로 道를 非道로 삼겠는가.78) // 세 번째는, 마음을 편안히 하는 것이다. $\cdots$ 생사가 열반이라 체득하는 것을 선정이라 하고, 번뇌가 보리라 체달 하는 것을 지혜라고 한다. 일심 가운데 교묘하게 선정과 지혜를 닦아 일체행을 구족한다.79) // 네 번째는, 파법편이다. $\cdots$ 만약 생사가 열반이

할지 모른다고 비판하고 있다. 그러므로 그 중요한 뜻을 뽑아 시작과 끝을 공통으로 하니, 유문의 도에 드는 관행을 알 수 있다고 한다. “阿毘晴中具此十意, 其文間散, 論師設欲行道, 不知依何而修. 如惑岐路, 莫識所從, 今撮其要意, 通冠始終, 則識有門 入道之觀也” (『大正藏』33, p.785c).

76)『법화현의』에는 실상에 들어가는 방법으로 장통별원 사교의 십승관법을 제시하고 있다. 장교의 십승관법은 비교적 자세하게 無常·無我·苦·空으로 또는 眞諦로 해석되고 있으며, 통교의 십승관법은 아주 간략하게 一切法空 또는 색에 즉한 진제로 설명되어 있으며, 별교의 십승관법은 차제로 생사(무명) · 열반(법성) · 중 도로 설명되고, 원교의 십승관법은 생사의 색에 즉한 법성의 색 또는 법성의 색에 즉한 생사의 색 즉 중제로 설명되고 있다. 또한 별교와 원교의 차이를 열 가지 즉 가 融不融, (나 師法不師法, 다 佛智非佛智, 라 次第不次第, 마 斷惑不斷惑, 바 實位不實位, 사 果縱果不縱, 아 圓詮不圓詮, 자 難問, 차 譬喻로 밝히는 가운데 원교의 뜻은 분명해진다.

77）三智一心中得名大般若. 淨名曰, “一切衆生師菩提相, 不可復得” 此師煩惱之集, 而是無作道諦, 亦是苦滅. 故名不思議一實四諦也. 亦是眞善妙色. 何者, 生死師空故 名眞, 生死師假故名善, 生死郎中故名妙. 次名有門不可思議境也(『大正藏』33, p.789c).

78）二發眞正心者, 一切衆生師大涅槃, 云何顛倒以樂爲苦. 師起大悲興兩誓願, 令未度者 度, 令未斷者斷. 一切煩惱, 師是菩提, 云何愚闇以道爲非道. 師起大悲興兩誓願, 令未 知者知, 令未得者得. 無緣慈悲, 淸淨誓願, 慈善根力, 任運吸取, 一切衆生也(『大正藏 』33, pp.789c-790a).

79) 三安心者, 睥體解成就發心具足, 豈可臨池觀魚不肯結網, 寒糧束脚安座不行. 修行之 要不出定慧. 譬如陰陽調適萬物秀實. 雨早不節焦瀾豈生. 若兩輪均平是乘能運, 二 
라면 분단과 변역생사의 고제는 모두 타파되고, 만약 번뇌가 보리라면 四住와 五住煩惱의 집제는 모두 타파된다. 또 타파하더라도 타파되는 것이 있지 않다. 왜냐하면 생사가 열반이기 때문이다. 따라서 타파되는 것도 없다.80) // 다섯 번째는, 통함과 막힘을 아는 것이다. $\cdots$ 생사의 근심을 아는 것을 막힘이라 하고, 열반에 즉함을 통함이라 한다. 번뇌의 괴로움과 어지러움을 막힘이라 하고, 이것이 바로 보리인 것을 통함이라 한다. 절절이 집착함은 막힘이요, 절절이 묘한 이치에 계합하는 것은 통함이라 한다.81) // 여섯 번째는, 도품을 잘 식별하는 것이다. 생사가 열반이라 관찰하면. $\cdots$ 또한 涅槃師生死라 아는 것은, 사라쌍수의 네 귀의 마름[四枯]을 드러내고, 生死剅涅槃이라 아는 것은, 사라쌍수의 네 귀의 무성함[四榮]을 드러낸다. 생사와 열반이 둘이 아니라 아는 것은, 하나의 실다운 진리이다. 번뇌가 마르지도 않고 증장하지도 않으므로 대열반에 머문다.82) // 일곱 번째는, 잘 닦아 대치하는 것이다. 만약 正道 에 장애가 많으면 助道를 써야 한다. 生死㓦涅槃이라 관찰하면 報障을 대치하고, 煩惱師菩提라 관찰하면 業障과 煩惱障을 대치한다.83) // 여덟 번째는, 차제의 계위를 잘 아는 것이다. 생사법이 본래 열반인 것은 이즉 의 열반이고, 生死師涅槃을 알아 깨닫는 것은 명자즉의 열반이며, 부지

翼具足堪任飛升. 體生死師涅槃名爲定, 達煩恛師菩提名爲慧. 於一心中巧修定慧, 具足一切行也(『大正藏』33, p.790a).

80）四破法徧者, 以此妙慧如金岡斧所擬皆碎, 如無掔日所臨皆朗. 若生死咱涅槃者, 分段 變易苦諦皆破，若煩惱郎菩提者，四住五住集諦皆破．雖復能破亦不有所破．何者， 生死師涅槃，故無所破也(『大正藏』33, p.790a).

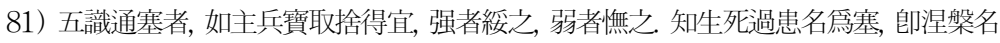

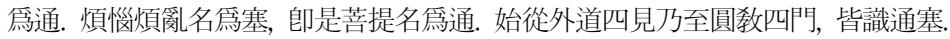
節節執著師是塞, 節節亡妙名爲通. 若不識諸法夷嶮, 非但行法不前, 亦亡去重寶也 (『大正藏』33, p.790a).

82）六善識道品者, 觀生死師涅槃, 十界生死色陰皆非淨非不淨, 乃至識陰非常非不常. 能破八顛倒, 六善識道品者, 觀生死師涅槃, 十界生死色陰皆非淨非不淨, 乃至識陰 非常非不常. 能破八顛倒, 即法性四念處. 念處中具道品三解脫及一切法. 又知涅槃 師生死顯四枯樹, 知生死師涅槃顯四榮樹. 知生死涅槃不二, 郎一實諦. 非枯非榮, 住大涅槃也(『大正藏』33, p.790a).

83）七善修對治者, 若正道多障, 應須助道, 觀生死師涅槃, 治報障也, 觀煩惱郎菩提, 治業 障煩惱障也(『大正藏』33, p.790a). 
런히 生死師涅槃을 관찰하면 관행즉의 열반이고 $\cdots$ 煩惱蛗菩提를 관찰 함도 이와 같다.84) // 아홉 번째는, 잘 참고 견디는 것이다. 내외의 강하고 부드러운 장애를 참아서 관심을 깨뜨리지 않는다. 만약 生死師涅槃이라 관찰하면, 陰入境・病患・業・魔・禪・毛・菩薩 등의 경계에 의해 흔들리거나 깨뜨려지지 않는다. 만약 煩惱師菩提라 관찰하면 모든 망견 과 교만의 경계에 의해 흔들리거나 깨뜨려지지 않는다.85) // 열 번째는, 법에 대한 애착을 없애는 것이다. $\cdots$ 生死師涅槃이라 관찰하기에 모든 선정삼매의 공덕이 일어나고, 煩儠師菩提라 관찰하기에 모든 다라니 · 사무소외 ·十八不共法의 모든 반야가 일어난다. 생사와 열반이 둘이 아 니라 관찰하기에 法身實相이 일어난다. 生死䄱涅槃이라 관찰하기에 해 탈을 증득하고, 煩惱師菩提이기에 반야를 증득한다. 이것을 有門으로부 터 진실에 들어가 경의 체를 증득한다고 한다. 나머지 삼문도 이와 같 다.86)

이와 같이 원교의 십승관법은 모두 생사즉열반 - 열반즉생사 또는 번뇌즉보리 - 보리즉번뇌만을 가지고 그 주안으로 삼고 있다. 이것은 『 마하지관』에서 十境에 따라 십승관법을 음입계경이나 번뇌경 또는 병 환경으로 설명하는 것과는 큰 대조를 보인다. 이것은 관부사의경부터 무법애에 이르는 관법에 圓融不二의 원리를 도입한 것으로서 행인으

84）八善知次位者, 生死之法本師涅槃, 理涅槃也. 解知生死㓥涅槃, 名字涅媻也. 勤觀生 死㴧涅槃, 觀行涅槃也。善根功德生, 師相似涅槃也。畺實慧起, 師分眞涅槃也。盡生死 底, 師究竟涅槃也. 觀煩惱師菩提亦如是(『大正藏』33, p.790a-b).

85）九善安忍者, 能安內外强煖遮障, 不壞觀心. 若觀生死師涅槃, 不爲陰入境 - 病患 業・魔 ・禪 - 二乘 ·菩薩等境所動壞也. 若觀煩恛師菩提, 不爲諸見增上慢境所動 壞也(『大正藏』33, p.790b).

86）十無法愛者, 既過障難, 道根成立, 諸功德生. 觀生死師涅槃, 故諸禪三昧功德生. 觀煩 惱師菩提, 故諸陀羅尼無畏不共諸般若生. 觀生死涅槃不二, 故法身實相生. 相似功 德順理而生. 喜起順道法愛生名法愛, 不上不退名萹頂隋. 此愛若起䒜當疾滅. 愛若 滅已破無明, 開佛知見證實相體. 觀生死師涅槃, 故證得解脫. 煩惱師菩提, 故證得般 若. 此二不二, 證得法身, 一身無量身. 無上寶聚如意圓珠衆法具足. 是名有門入實證 得經體. 餘三門亦如是(『大正藏』33, p.790b). 
로 하여금 즉공즉가즉중으로 관찰하게끔 하는 것이다. 그러면 이렇게 법화의 체현의를 설명하는 가운데 십승관법을 밝히는 이유는 무엇인 가. 그것은 법화의 體玄義인 실상에 들어가게 하기 위한 관문으로 십 승관법을 제시한 것 이외에 다른 것이 아니다. 굳이 오행과 같이 경전 에 직접 나오는 관행이 제시되지 않고 십승관법과 같이 智顗가 조직한 관법이 나오는 것에 대해선 行과 位의 차이를 엄밀하게 따져봐야 할 것이다.

이런 맥락에서 십승관법이 바로『법화경』의 뜻임을 확인시키기 위 해 법화의 경문을 빌려 십승관법을 인증하고 있다.87)『법화현의』는 圓 融十義와 圓呚四門 및 원교 십승관법의 인증문을 『법화경』에서 애써 찾아 보이고 있다.88)『법화현의』초두에 밝힌 바와 같이 법행인에 맞 춘 관법이 십승관법이라는 점은, 법화의 체현의를 밝히는 중에 십승관 법이 소개되어 있는 점과 그대로 맥을 같이 한다. 십승관법을 가지고 실상으로 통하는 관문을 소개하는 『법화현의』는, 이것만 가지고도『마 하지관』에서 밝히지 못한 십승관법의 제정이유를 분명히 하게 되는 것이다. 智顗에게 있어서 觀心은 實相의 총결이라 해도 과언은 아니다. 왜냐하면 제법의 근본원리인 실상은 적어도 법행인에게 있어서는 十

87)『妙法蓮華經』卷1 「方便品」第2 “如是大果報, 種種性相義, 我及十方佛, 乃能知 是事, 是法不可示, 言辭相寂滅, 諸餘衆生類, 無有能得解, 除諸菩薩衆, 信力堅 固者”(『大正藏』9, p.5c. 高麗大藏經 K.116, V.9, p.729c).

88）智顗說, 『妙法蓮華經玄義(『大正藏』33, p. $790 \mathrm{~b}-\mathrm{c}$ ) 是十種觀經文具足. “是法不可 示, 言辭相寂滅, 諸餘衆生類無有能得解.”又 “我法妙難思.” 師不思議境. “於一切衆 生中起大慈心, 於非菩薩中起大悲心. 我得三菩提時, 以神通力智慧力引之令得住是 法中.”㴧正發心也. “佛自住大乘, 如其所得法, 定慧力莊嚴.” 師是安於二法自成成他 也. “破有法王.” 師是破法徧也. 又 “如日月光明能除諸幽瞑, 斯人行世間能破衆生 闇.” 㴧破法徧也. “有一導師將導衆人, 明了心決定在嶮濟衆難.” 善知通塞也. 淨藏淨 眼修三十七品諸波羅蜜, 師是兩意也. “增道損生遊於四方.”師是識次位也. “安住不 動如須彌頂. “著如來衣.” 師安忍也. “雖聞是諸聲, 聽之而不著. 其意等六根皆言淸 淨若此.” 又云 “䢐淨大法.” 師無法愛也. 
乘觀法을 통해서만 들어갈 수 있기 때문이다.

\section{7. 敎相玄義手 三種敉觀}

오중현의 가운데 다섯째 教相을 판석하는 장은 여섯으로 나누어 설 명하는 중89) 첫째 三種敉相의 대강을 서술하는 가운데 觀心을 개진하 고 있다. 大綱節에는 三種敉相을 설명한 이후에 觀門으로 三種止觀이 서술되어 있다. 즉 呚門으로서의 頓・漸-不定의 三種敉相에 대응하 여 觀門으로 圓頓・漸次・不定의 三種止觀을 제시하고 있다.90) 大綱 節에서는 돈점부정을 다음과 같이 교문과 관문으로 설명하고 있다.

첫째 대강에는 세 가지가 있다. 첫째는 頓이요, 둘째는 漸이요, 셋째는 不定이다. 이 세 가지 명칭은 옛 것과 같으나, 뜻은 다르다.91) 이제 이 세 교를 해석함에 있어서 각각 두 가지로 해석한다. 첫째는 呚門에 따라 해석하고 둘째는 觀門에 따라 해석하는 것이다. 교문은 信行人을 위한 것으로서 多聞의 뜻을 이루는 것이다. 觀門은 法行人을 위한 것으로서

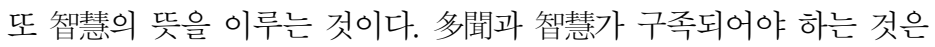
마치 사람이 눈이 있어도 해의 광명으로 비추어야 여러 가지 형색을 볼 수 있는 것과 같으니 모든 것이 대지도론의 게와 같다.92) 운운.

89）智顗說, 『妙法蓮華經玄義』『大正藏』33,p.806a）五判敎相者, 郎爲六：一擧大綱, 二引三文證，三五味牛滿相成，四明合不合，五通別料簡，六增數明敉.

90）智顗說，『妙法蓮華經玄義』『大正藏』33，p.806b-c) “二約觀明義者. 一圓頓觀... 二漸次觀. 不定觀者.”

91）智顗說, 『妙法蓮華經玄義』『大正藏』33, p.806a) 一大綱三種. 一頓, 二漸, 三不定, 此三名, 同舊義異也.

92) 智顗說, 『妙法蓮華經玄義 (『大正藏』33, p.806a) 今釋此三敎, 各作二解 : 一約敎門 解, 二約觀門解, 教門爲信行人. 又成聞義, 觀門版法行人. 又成慧義, 聞慧具足, 如人 有目日光明, 照見種種色具, 如釋論偈. 云云. 
敎門인 頓・漸 - 不定의 三種敉相에 대응하여 觀門인 圓頓觀・漸次 觀・不定觀의 三種止觀이 함께 제시되면서 信行의 多聞과 法行의 智 慧를 구족토록 하는 것이 그 목적임을 알 수 있다.93) 三種敉相과 이에 상응하는 三種止觀의 뜻을 도시하면 다음과 같다.

$<$ 표1 $>$ 三種敉相과 三種止觀

\begin{tabular}{|c|c|}
\hline 三種敎相 & 三種止觀 \\
\hline 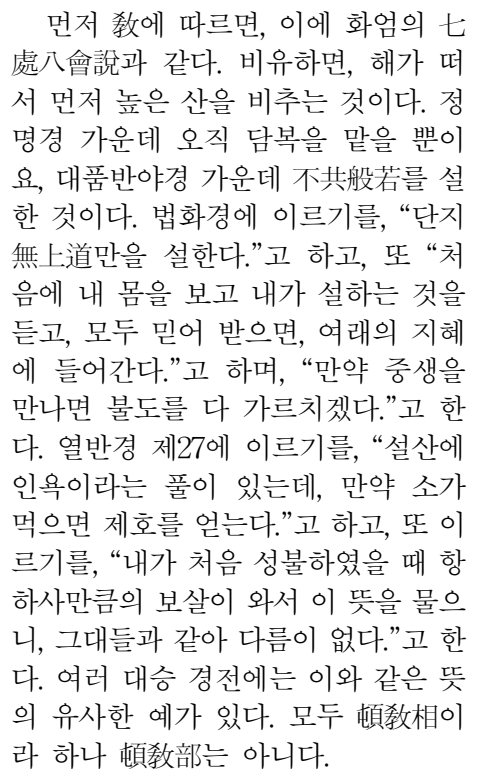 & 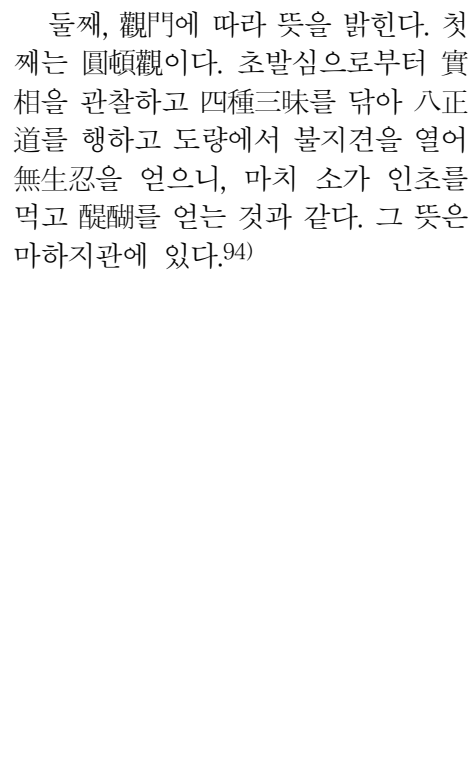 \\
\hline
\end{tabular}

둘째, 漸敉相이란, 열반경 제 13 에 서 이르는 것과 같이, "부처님으로부 터 十二部經이 나오고, 十二部經에서 修多羅가 나오며, 修多羅에서 방등경
둘째는 漸次觀이다. 초발심부터 원 만하고 구극하기 위해 阿那波那, 十二 門樿을 닦는 것이니, 이것은 근본행이 다. 그러므로 이르기를, "범부는 잡혈

93）智顗說，『妙法蓮華經玄義』( 大正藏』46, p.806b).

94）智顗說, 『妙法蓮華經玄義』 (大正藏』46, p.806b-c) 二約觀明義者. 一圓頓觀, 從初發 心㴧觀實相, 修四種三昧, 行八正道, 師於道場, 開佛知見, 得無生忍. 如牛食忍草, 師得醍醐. 其意具在止觀. 
이 나오고, 방등경에서 반야가 나오 며, 반야에서 열반이 나온다.”고 하니, 이와 같은 것들의 뜻이 漸敉相이다. 또한 처음 인천으로부터 이승-보 살-불도에 이르는 것도 점교상이다. 또한 중간에 차례로 들어가는 것도 漸 呚相이다. $\cdots$
유와 같다.”고 한다. 다음은 六妙門, 十六特勝, 觀練熏脩 등, 내지 三十七 道品, 四諦觀 등을 닦으니, 이것은 성 문법으로서, 청정유의 수행과 같다. 다음은 十二緣觀을 닦으니, 이것은 연 각으로서, 酪의 수행과 같다. 다음은 四弘誓願, 六度를 닦으니, 이것은 통 교와 장교의 보살이 행하는 현상과 본 체의 법으로서, 모두 生蘇의 수행과 같다. 다음은 별교보살이 닦는 수행은 모두 熟蘇와 같으니, 그러므로 이르기 를, 보살은 熟蘇와 같다고 하는 것이 다. 다음은 自性樿을 닦아 一切樿 내 지 淸淨頂樿에 들어가니, 이러한 모든 법문은 불성을 보고 대열반에 머물러 진실을 구족하므로 醍醐의 수행이라 고 하는 것이다. 만약 보살위에 대하 여 五味의 뜻으로 판별하면, 앞의 행 묘 가운데 판별한 것과 같고, 또한 차 제선문에서 설한 것과 같다.95)
셋째, 不定呚란, 이것은 따로 법이 없고, 다만 頓漸에 따라 그 뜻이 자명 해진다. 지금 대반열반경 제 27 에서 이 르는 것에 의하면, "우유에 독을 넣으 면 우유는 사람을 죽이고, 酪·生蘇· 熟蘇 - 醍酤도 사람을 죽일 수 있다." 고 한다. 이것은 과거 부처님 처소에 서 일찍이 대승실상의 가르침을 듣던 것을 말한다. 그것을 독으로 비유하였 던 것이다. 지금 석가의 聲敉를 만나 니, 독이 발하여 미혹된 사람을 죽인 다. 만약 제위파리경과 같으면 $\cdots$ 이
셋째는 不定觀이다. 과거불로부터 깊이 선근을 심어, 지금은 十二門樿을 닦아 증득하고 활연히 개오하여 無生 忍을 얻으면, 이것은 우유에서 독이 살인하는 것이다. 만약 앉아 不定觀, 九想, 十想, 八背捨, 八勝處, 有作四聖 諦觀 등을 증득하여, 이러한 선정으로 인하여 활연히 마음을 열어 뜻을 이해 하고 無生忍을 얻으면, 이것은 독이 酪에서 살인하는 것이다. 만약 어떤 수행인이 四弘誓願을 발원하고 六度 를 닦아 가제를 체득하여 공제로 들어

95) 智顗說, 『妙法蓮華經玄義』(『正藏』46, p.806c)二漸次觀. 從初發心, 爲圓極故, 修阿那波那, 十二門禪, 師是根本之行. 故云：凡夫如雜血乳 次修六妙門, 十六特勝, 觀練熏修等, 乃至道品, 四諦觀等, 郎是聲聞法, 如淸淨乳行也。次修十二緣觀, 郎是緣 覺, 如酪行也. 次修四弘誓願, 六波羅蜜, 通藏菩薩, 所行事理之法, 皆如生蘇行也. 次修別敎菩隡所行之行, 皆如熟蘇. 故云 : 菩薩如熟蘇也. 次修自性禪入一切樿, 乃至 清淨浖禪. 此諸法門, 能見佛性, 住大涅槃, 眞應具足. 故名醍醐行也. 若的就菩薩位, 辨五味義, 如上行妙中辨, 亦如次第樿門說也. 
것이 우유 가운데서 살인하는 것이다. 酪 가운데에서 살인하는 것이란, 대지 도론에서 이르는 것과 같이, 교에는 두 가지 종류가 있는데, 하나는 顯露 呚이고, 하나는 秘密敎이다. $\cdots$ 이것 이 독이 酪에 이르러 살인하는 것이 다. 生蘇 가운데 살인하는 것은, 여러 보살이 방등대승교에서 불성을 보고 대열반에 머무르는 것이 그 뜻이다. 熟蘇 가운데 살인한다는 것은, 여러 보살이 마하반야교에서 불성을 보는 것이 그 뜻이다. 醍醐 가운데 살인한 다는 것은, 열반교 중에서와 같이 둔 한 근기의 성문이 혜안을 개발하고 불 성을 보고 내지 둔한 근기의 연각과 보살이 일곱 가지 방편으로 모두 구경 열반에 들어가는 것이 그 뜻이다. 이 것을 不定敉相이라 한다. 不定部는 아 니다.
가고 無生四諦觀을 닦아 활연히 깨달 아 이해하고 無生忍을 얻으면, 이것은 독이 生蘇에서 살인하는 것이다. 만약 수행인이 六度를 행하고 공제로부터 가제로 벗어나는 것을 닦고 無量四諦 觀을 닦아 활연히 마음을 깨닫고 無生 忍을 얻으면, 이것은 독이 熟蘇에 이 르러 살인하는 것이다. 만약 좌선하여 中道自性禪의 정관을 닦고 無作四聖 諦를 배우며 法華三昧와 般舟三昧 등 의 四種三昧를 행하여 활연히 마음을 깨달아 無生忍을 얻으면, 이것은 醍醐 의 수행 가운데에서 살인하는 것이 다.96)

이와 같이 교상은 대체로 화엄, 방등, 반야, 법화, 열반 등 五時 경전 으로 판별하고 있고 지관은 四種三昧를 비롯하여 阿那波那과 같은 선 정삼매와 四弘誓願 및 六度 그리고 四種의 四諦觀의 지혜 등을 가지고 판별하고 있다. 따라서 교와 관이 각각 대소승의 경전과 선정과 지혜 임이 확인된다. 특히 삼종지관은 智顗 스스로 밝히는 바와 같이 행묘 단에서 밝힌 바와 같다고 하므로 이것으로 교와 관의 규격을 분명히 알 수 있다. 더구나 信行과 法行의 두 행을 판별해 佛法에 각각 세 가

96）智顗說,『妙法蓮華經玄義（『大正藏』46, p.806c) 不定觀者. 從過去佛, 深種善根, 今修登十二門, 豁然開悟, 得無生忍, 師是毒在乳中, 師能殺人也. 若坐證不淨觀, 九 想 十想, 背捨, 勝處, 有作四聖諦觀等, 因此樿定, 豁然心開, 意解, 得無生忍, 師是毒至 酪中殺人也. 若有人, 發四弘誓願, 修於六度, 體假入空, 無生四諦觀, 豁然悟解, 得無 生忍, 郎是毒至生蘇殺人也. 若人修行六度, 修從空出假, 修無量四諦觀, 豁然心悟, 得無生忍, 是毒至熟蘇, 而殺人也. 若有坐禪, 修中道自性等禪正觀, 學無作四聖諦, 行法華般舟等, 四種三昧, 豁然心悟, 得無生忍, 師是醍醐行中殺人也. 
지 뜻이 있다고 하면서, 앞의 온갖 敎相은 한 科도 법사들과 다르지 않 은 것이 없고, 만약 선정을 닦고 도를 배우고자 한다면, 앞의 모든 지관 은 두루 法行人을 위하여 안심법을 설한 것이니, 한 科도 세간의 선사 와 같은 바가 없다고 하면서 이것을 간략하게는 교관의 대의라 하고 크게는 불법에 두루하다고 명언하여 一經一論이나 一禪一定에 치우치 는 文字法師나 闇登禪師와의 차별을 분명히 하고 있다.97) 삼종교관은 『法華玄義』이외에『摩訶止觀』에서도 설명되어 있지만 이 大綱節에 교와 관이 보다 典刑적으로 이루어져 있다고 할 수 있다. 이러한 삼종 교관은 앞 칠번공해에서 강조한 신행과 법행과도 맥락을 같이한다.98)

\section{8. 天台의 觀觀論}

『법화현의』는 오중현의를 칠번공해와 오중각석으로 풀이하는 가운 데 칠번공해에서는 관심단을 설정하여 프뵤에 대한 철저한 관심을 요 구하고 있고, 오중각석에서는 명체종용교마다 관심단을 제정하여 교 상을 관심하도록 강하게 주장하고 있다. 칠번공해에서 관심단을 설정 하여 標章・引镫・生起·開合・料簡을 관심토록 한 것은 연구방법론 인 칠번공해마저 관심함으로써 교관쌍수를 취하도록 하는 것이다. 이 런 토대 위에 오중현의마다 관심단을 제정하고 있다. 명현의에서는 적 문십묘와 본문십묘로 설명하는 중에 각 장과 각 절에서 妙法을 관심하 도록 철저하게 요구하고 있다. 특히 行妙에서는 행법을 五行의 次第와

97）智顗說, 『妙法蓮華經玄義』『大正藏』46, p.806c) 今辨信法兩行, 明於佛法, 各作三意, 歷前諸敉, 無有一科, 而不異諸法師也. 若欲修禪學道, 歷前諸觀, 䳕法行人, 說安心 法, 無有一科, 與世間禪師同也. 是名, 略點敎觀大意, 大該佛法.

98）智顗說, 『妙法蓮華經玄義』(『正藏』33, p.806c) “今辨信法兩行, 明於佛法, 各作三 意, 歷前諸敉, 無有一科, 而不異諸法師也. 若欲修樿學道, 歷前諸觀, 爲法行人, 說安 心法, 無有一科與世間禪師同也. 是名, 略點教觀大意, 大該佛法.” 
圓融으로 소상하게 밝히고 있으며, 位妙에서는 원교의 계위에서 행하 는 관법을 십승관법으로 제시하고 있다. 그리고 경자 해석에서는 경교 를 대하는 관심의 사례를 구체적으로 밝힘으로써 경교와 관심을 하나 로 묶고 있다. 체현의에서는 實相에 들어가도록 십승관법으로 철저하 게 관심토록 한다. 여기서 소개하는 십승관법은 『摩訶止觀』의 본령인 正修章의 십승관법과 체계적으로는 다름이 없으나 이 십승관법은 有 門觀에 의해 해석한 것이 空門에 의해 해석하는 『摩訶止觀 과는 좋은 대조를 보인다. 또한 十境에 따라 十乘觀法을 풀이한 『摩訶止觀 과는 달리 四敉 또는 四門 및 別圓의 명확한 구별을 통해 십승관법에 대해 폭넓은 이해를 갖게끔 한다. 마지막으로 교상현의에서는 삼종교상과 삼종지관을 대조시킴으로써 교관의 雙修가 완결된다. 이것이 천태교 관체계의 백미라는 점에서 천태의 구극은 바로 呚相과 觀心의 相資에 있다고 할 것이다.

그렇다고 하면 교문 저작인 『法華立義』에 왜 이토록 敎相 이상으로 觀心이 강조된 것인가. 이것은 『법화경』의 현의를 밝히는 교상의 단순 한 이해보다는 『법화경』의 실상묘법을 수증하는 것에 궁극적 의의가 있음을 절감한 읍顗가 교관겸수의 특색을 유감없이 발휘한 것이라 볼 수 있다. 평생 수증으로 일관한 智顗로서는 觀心이 實相妙法의 총결이 라 해도 과언이 아닌 이상, 제법의 근본원리인 제법실상은 관문을 통 해서만 들어갈 수 있으나 그럼에도 관심을 하지 않는 문자의 법사를

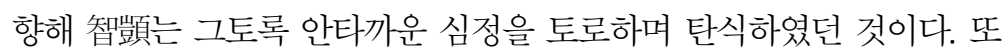
한 실상묘법에 대한 이해가 관심을 이끈다는 점에서 교상적 이해를 무 시하는 암증의 선사를 향해 智顗는 뼈저린 심정으로 무척이나 애석해 하고 질타했던 것이다. 『법화경』의 교상과 관법을 통해 證悟를 이룬 智顗는 㸚나 觀에 치우치는 문자의 법사와 암증의 선사를 동시에 비판 하면서 행인들에게 교관겸수의 가르침을 제시한 것은 분명하다. 더구 
나 관심을 가지고 실상묘법으로 통하는 길을 밝힌 智顗로서는 『법화현 의』가 법화의 현의를 밝히는 교문저작이라는 점에서 관심에 대한 강조 에 더욱 유별난 모습을 보였다고 하겠다.

그러므로 신행인을 위한 多聞의 교문과 법행인을 위한 智慧에 의한 관문을 아우르고 있는 『法華玄義』에서, 智顗가『法華玄義』에서 표방 하고자 한 것은 聞慧具足과 呚觀廉修라 단언해도 과언은 아니다. 비록 삼종교상은 多聞인 신행인을 위한 것이고, 삼종지관은 智慧인 법행인 을 위한 것이라 할지라도 智顗는 신행인을 위해서나 법행인을 위해서 나 聞慧兼修와 㸚觀雙修를 주창한 것이다. 오중현의 전체를 통하여 開 顯 뒤에 바로 觀心을 둔 것은 聞慧를 구족케 하는 것이 그 목적이라 할 수 있다. 이로 인해『法華玄義』에서 開顯과 함께 觀心이 두 축을 이 루고 있으므로『法華立義』 전편을 통하여 觀心을 체득해가는 방법이 교상저작임에도 불구하고 관심저작 못지않게 조직적으로 설명되어 있 는 것이다. 이런 점에서『법화현의』는 그대로 교리수행론이라 할 수 있다. 이러한 『법화현의』의 교관론은 『법화경』의 현의를 圓融敉相과 圓頓止觀으로 해석하면서 문혜겸수와 교관쌍수를 역설하였을 뿐만 아 니라 대소승을 막론한 불교 경전을 四敉의 교상과 관심으로 조직함으 로써 복잡다단한 불교 교리와 수행을 체계화한 것이다. 결론적으로 말 하면 『법화현의』는 經呚와 禪觀이 절묘하게 만나는 독보적이고 탁월 한 교관 저작이라 해도 좋을 것이다. 


\section{참고문헌}

智 顗

『法華文句』10권

『大正藏』 34

『法華玄義』10권

『大正藏』 46

『摩訶止觀』10권

『大正藏』46

『維摩經立疏』6권

『大正藏』38

『維摩經文疏』28권

『乙續藏』28

灌 頂

『大般涅槃經玄義』2권

『大正藏』38

『大般涅槃經疏』33권

『大正藏』38

湛 然

『法華文句記』30권

『大正藏』 34

『法華玄義釋籤』20권

『大正藏』36

『止觀輔行傳弘決』40권

『大正藏』46

『止觀輔行搜要記』10권

『續藏』99

『止觀義例』1권

『大正藏』 46

『止觀大意』1권

『大正藏』 46

『三大部科文』16권

『續藏』43

『法華五百問論』3권

『乙續藏』100

『維摩經略疏』10권

『大正藏』38

『維摩經疏記』3권

『凹續藏』28

『法華經大意』1권

『乙續藏』43

前田慧雲，『天台宗綱要』，東洋大學出版部

天台宗務廳學學部，台學階梯，『敎觀講要』，天台發行所

谷慈弘，『天台宗讀本』，天台宗務廳呚學部，1939.

二宮守人, 『天台の敎義と信仰』, 國書刊行會, 1977.

島地大等，『㸚學史』，中山書院，1978 (1929).

, 『敎理と史論』, 中山書院, 1931.

福田堯穎, 『天台學概論』, 三省堂, 1954. 
，『續 天台學概論』文一出版, 1959.

山口光圓, 『天台概說』, 法藏館,

藤浦慧嚴, 『天台䍩學と淨土敎』, 淨土教報社, 1942.

石津照需、『天台實相論の研究』，創文社，1980（1947）.

安藤俊雄, 『天台性具思想論』, 法藏館, 1953.

，『天台思想史』, 法藏館, 1959.

，『天台學』，本樂寺，1969.

, 『天台學論集』, 平樂寺書店, 1975.

關口眞大, 『天台止觀の研究』, 岩波書店, 1969.

編,『止觀の研究』, 岩波書店, 1975.

編, 『天台敉學の研究』，大東出版社，1978.

佐藤哲英, 『天台大師の研究』, 百華苑, 1961.

，『續 天台大師の呼究』, 百華苑, 1981.

佐佐木憲德, 『天台敎學』, 百華苑, 1963 (1951).

，『天台緣起論展開史』，永田文昌堂, 1953.

玉城康四郎，『心把捉の展開』，山喜房佛書林，1975 (1961).

日比宣正, 『唐代天台學序說』, 山喜房佛書林, 1966.

，『唐代天台學磻究, 山喜房佛書林, 1975.

新田雅章, 『天台實相論研究』, 日本 本樂寺, 1969.

，『天台思想入門』，日本 第三文明社,1977.

，『天台哲學入門』，第三文明社, 1977.

池田魯參, 『國清百錄の研究』, 大藏出版, 1982.

，『摩訶止觀㸴究序說』, 大東出版社, 1986.

村中祐生, 『天台觀門の基調』, 山喜房佛書林, 1986.

大野榮人, 『天台止觀成立史の研究』, 法藏館, 1994.

田村芳朗, 梅原猛, 『絶對の眞理 天台, 佛敉の思想 5』, 角川書店, 1970.

京戶慈光, 『天台大師の生涯』, 第三文明社, 1975.

田村芳朗 新田雅章, 『智顗 人物 中國の人物』, 大藏出版, 1982.

鎌田茂雄, 『天台思想入門』, 講談社, 1984 .

荷日宣, 『法華經一乘思想の研究』, 山喜房, 1975.

雙谷定彦、『法華經一佛乘の思想』, 東方出版, 1985.

布施浩岳, 『法華經成立史』, 大東出版社, 1938.

金倉圓照, 『法華經の成立と展開』，本樂寺書店，1970. 
坂本幸男 編, 『法華經の思想と文化』，本樂寺書店, 1968 .

坂本幸男,『法華經の中國的展開』, 本樂寺書店, 1972 .

横超慧日, 『法華思想の研究』, 平樂寺書店, 1975.

，『法華思想, 平樂寺書店, 1980.

鹽田義遜、『法華敎學史の㸴究』, 日本圖書, 1978.

，『法華經の研究』，日本圖書，1978.

丸山孝雄,『法華教學碩究序說』, 本樂寺書店, 1978.

中村瑞隆,『法華經の思想と基盤』, 平樂寺書店, 1980.

望月海淑,『法華經における信の研究序說』, 山喜房, 1980.

平川彰 外, 『法華思想 講座大乘佛敉 4』, 春秋社, 1983.

\section{[Abstract]}

A Theory of Observation of Mind in the Fa-bua-xuan-yi

Ji, Chang-gyu

The Fa-bua-xuan-yi (法華玄義) interprets the doctrine of the Lotus Sutra, and it is considered as one of the key writing about doctrine. So it is understood that the book may differ from Chih-I (智顗)'s practice, and it focuses on the demonstration of the doctrine of the Lotus Sutra. In addition, the writing describes the representative organization of periods and orders of teachings such as the Five Periods and Eight Teachings, so it was known as a book of categorizing the period and order of teachings. However, the Fa-bua-xuan-yi, which is a fundamental basis of the doctrine of Tien-Tai and identifies the doctrine of Myo-beop-yeonbwa-gyeong (妙法蓮華經: the Lotus Sutra), shows a bit different view of observation of mind.

The Fa-bua-xuan-yi interprets the five types of doctrines with the seven 
hermeneutical steps (七番共解) and the five explanations (五重各釋). The seven hermeneutical steps establish the objects of observation and demand through observation of the five steps. The five explanations establish the objects of observation in each doctrine (名, 體, 宗, 用, 教) and demand observation of doctrines. The seven hermeneutical steps require observation of Pyo-jang (標章), In-jung (引證), Saeng-gi (生起), Gae-hap (開合), and Yo-gan (料簡). This is because by letting people observe a research method, the seven steps of interpretation, people may achieve the status of integration of a doctrine and observation. On the basis of this, the book establishes the objects of observation in each of the five types of doctrine: the doctrine of name interpretation (名玄義) suggests five perfect practices, the ten stages of meditation and the observation of sutra to observe the marvelous teachings; the doctrine of essence interpretation (體玄義) suggests ten stages of meditation to observe the true nature of dharma; the doctrine of teaching interpretation (㸚相立義) suggests the three kinds of doctrine and observation to observe the admirable Buddha nature.

Then, what is the reason that the Fa-bua-xuan-yi emphasizes the observation of mind more than the doctrine? It seems that Chih-I (智顗) realizes ultimate significance of the practice of the true nature of dharma from the Lotus Sutra rather than a simple understanding of the doctrine of the Lotus Sutra, and fully demonstrates the characteristic of the integration of doctrine and observation. So, it is no exaggeration to say that the observation of mind is a final objective of the true nature of dharma for Chih-I who paid attention to the practice throughout his life. A fundamental principle of dharma, the true nature of dharma can be achieved by observation, so Chih-I lamented over those who don't practice the 
observation of mind and also sharply rebuked monks who neglect the understanding of the doctrine, because, on the basis of understanding the true nature, the understanding of the true nature of dharma brings the observation of mind. Chih-I attained enlightenment through the doctrine and the method of observation of the Lotus Sutra, and criticized monks who were biased by a doctrine or a method of observation, and also presented a teaching of the integration of doctrine and method of observation to the practicing monks. Moreover, Chih-I shed light on the way to the true nature dharma with the observation of mind, and in terms of that, the Fa-bua-xuan-yi is the book of doctrine that identifies the doctrine of the Lotus Sutra, he put more emphasis on the observation of mind.

As mentioned above, locating the observation of mind behind the Gae-hyun (開顯: revealing) in the five types of doctrines is to attain the wisdom by learning teachings. With this, the observation of mind occupies a central part in the Fa-bua-xuan-yi rather than the Gae-byun (開顯: revealing). The Fa-bua-xuan-yi provides categorized explanations about a procedure of obtaining an observation of mind, even though the book is about the doctrine rather than the observation of mind. The system of the doctrine and the observation method in the Fa-bua-xuan-yi interpret the doctrine of the Lotus Sutra with an integration of the doctrine (圓融教相) and an integration of the Śamatha vipasyana (圓頓止觀). The writing emphasizes the integrated practice with wisdom obtained from teachings and the integration of the doctrine and the observation method; also it systemizes the complex Buddhist teachings and the practice by organizing the doctrine and the observation method of the Four Doctrines regardless of Mahayana and of Hinayana Buddhism. In conclusion, the Fa-bua-xuan-yi 
is a outstanding writing about the doctrine and observation method that combines the doctrine of teachings with meditation and observation.

Key words: Fa-bua-xuan-yi (法華玄義), integration of the doctrine (圓融教 相), integration of the Samatha vipasyanā (圓頓止觀), seven hermeneutical steps (七番共解), five explanations (五重各釋)

지창규는 동국대학교 대학원 불교학과에서 박사학위를 받았으며, 현재 동 국대학교 불교학부 교수이다. 관심분야는 법화학과 천태학이며, 저서로는 『천 태사상론』이, 역서로는 『천태사교의 역주』가 있으며, 이외에 다수의 논문이 있다.

[2010. 11. 19. 투고; 2010. 12. 15. 수정; 2010. 12. 17 채택] 